\title{
LIDAR and other evidence for the southwest continuation and Late Quaternary reactivation of the Norumbega Fault System and a cross-cutting structure near Biddeford, Maine, USA
}

\author{
Ronald T . Marple ${ }^{1}$ and James D. Hurd, Jr. ${ }^{2}$ \\ 1. 403 Wickersham Avenue, Fort Benning, Georgia 31905, USA \\ 2. Department of Natural Resources and the Environment, The University of Connecticut, 1376 Storrs Road, \\ Storrs, Connecticut 06269-4087, USA \\ Corresponding author <ronmarple@verizon.net $>$
}

Date received: 14 April 2019 g Date accepted: 01 September 2019

\begin{abstract}
High-resolution LiDAR (light detection and ranging) images reveal numerous NE-SW-trending geomorphic lineaments that may represent the southwest continuation of the Norumbega fault system (NFS) along a broad, 30- to 50-km-wide zone of brittle faults that continues at least $100 \mathrm{~km}$ across southern Maine and southeastern New Hampshire. These lineaments are characterized by linear depressions and valleys, linear drainage patterns, abrupt bends in rivers, and linear scarps. The Nonesuch River, South Portland, and Mackworth faults of the NFS appear to continue up to $100 \mathrm{~km}$ southwest of the Saco River along prominent but discontinuous LiDAR lineaments. Southeast-facing scarps that cross drumlins along some of the lineaments in southern Maine suggest that late Quaternary displacements have occurred along these lineaments. Several NW-SE-trending geomorphic features and geophysical lineaments near Biddeford, Maine, may represent a 30-km-long, NW-SE-trending structure that crosses part of the NFS. Brittle NWSE-trending, pre-Triassic faults in the Kittery Formation at Biddeford Pool, Maine, support this hypothesis.
\end{abstract}

\section{RÉSUMÉ}

Des images haute résolution prises par LiDAR (détection et télémétrie par ondes lumineuses) dévoilent de nombreux linéaments orientés du NE vers le SO qui pourraient représenter la continuité au sud-ouest du système de failles de Norumbega (SFN) le long d'une vaste zone de 30 à $50 \mathrm{~km}$ de largeur de failles cassantes qui se poursuit sur au moins $100 \mathrm{~km}$ à travers le sud du Maine et le sud-est du New Hampshire. Ces linéaments se caractérisent par des dépressions et des vallées linéaires, un réseau hydrographique linéaire, des virages abrupts dans les rivières et des escarpements linéaires. Les failles de la rivière Nonesuch, de South Portland et de Mackworth du SFN semblent se poursuivre jusqu'à $100 \mathrm{~km}$ au sud-ouest de la rivière Saco, le long de linéaments proéminents, mais 
discontinus, mis en lumière par LiDAR. Les escarpements orientés vers le sud-est qui traversent des drumlins le long de certains des linéaments du sud du Maine donnent à penser que des déplacements remontant à la fin du Quaternaire se sont produits le long de ces linéaments. Plusieurs objets géomorphiques et linéaments géophysiques orientés du NO au SE près de Biddeford, au Maine, pourraient représenter une structure de $30 \mathrm{~km}$ de longueur allant du NO vers le SE et traversant une partie du SFN. Les failles cassantes orientées du NO au SE, datant d'avant le Trias et présentes dans la formation de Kittery à Biddeford Pool appuient cette hypothèse.

[Traduit par la redaction]

\section{INTRODUCTION}

The Norumbega fault system (NFS) is a NE-SW-trending, predominantly dextral transpressive fault system that continues from southwestern New Brunswick to the Saco River in southern Maine (e.g., Ludman and West 1999) (Fig. 1). It is generally characterized by a zone of dextral shear tens of kilometres wide containing numerous $<1 \mathrm{~km}$ wide mylonite zones (West and Hubbard 1997; Wang and Ludman 2004). The NFS dips steeply to the northwest and offsets the Moho (Doll et al. 1996). Dextral shear along the NFS began during the Middle Devonian and may have exceeded $100 \mathrm{~km}$ (Ludman et al. 1999). Additional dextral strike-slip motion occurred along the NFS in northeastern Maine during the Late Devonian(?) through Mississippian and then changed to oblique, reverse-sinistral motion during the Permian (Wang and Ludman 2003). Normal displacements occurred along the NFS during TriassicJurassic rifting (Goldstein and Hepburn 1999) and again during the Early Cretaceous (Roden-Tice and West 2003).

The continuation of the NFS southwest of Casco Bay, Maine, has been controversial. Goldstein and Hepburn (1999) and Hibbard et al. (2006), for example, suggested that the NFS continued to the southwest along the ClintonNewbury, Lake Char, Honey Hill, Wekepeke, and Bloody Bluff faults in southern New England, none of which have the same kinematics, orientation, and timing of deformation as the mid-Paleozoic dextral NFS (Goldstein and Hepburn 1999). Bothner and Hussey (1999) suggested that the NFS may be correlated with the Portsmouth fault zone in coastal New Hampshire and the Calef and Nannie Island faults in southern Maine and New Hampshire (Fig. 1). The Calef fault, however, shows no evidence for dextral movement (Gentry et al. 2018). Kuiper and Wakabayashi (2018), in contrast, postulated that the NFS ends abruptly near Biddeford, Maine, along a transform fault associated with a Devonian triple junction. However, the aeromagnetic and gravity anomaly maps of Daniels and Snyder (2004) and multibeam sonar data offshore (Marple and Hurd 2019) show no evidence for such a transform fault.

Our main goal in this study is to use primarily LiDAR data to determine if the NFS continues southwest of the Saco River. Our results reveal a $35-$ to $50-\mathrm{km}$-wide zone of mostly NE-SW-oriented lineaments that continue at least $100 \mathrm{~km}$ southwest of the Saco River (Figs. 2 and 3). They also reveal several NW-SE-trending features near Biddeford, Maine, that cross the trend of the NFS.

\section{METHODS AND DATA USED}

The LiDAR data used for this study were acquired from the MEGIS (2016) and NH GRANIT (2016) websites. We used the Hillshade tool of ArcGIS to generate shaded relief images from the DEM data using various illumination azimuths, an elevation angle of $25^{\circ}$, and a vertical exaggeration of ten times. Unless otherwise stated, the illumination azimuth used for images in this study was $080^{\circ}$. Color relief images were then generated using a color scheme based on elevations of the terrain. Basic contrast enhancement routines of Adobe Photoshop were used to digitally enhance the LiDAR images. Low contrast images were enhanced further using the intensity-hue-saturation (IHS) routine of Adobe Photoshop. We were not able to generate elevation scales for these images because the IHS enhancement significantly changes their color schemes. The LiDAR data were also used to construct detailed topographic profiles across selected features to quantify elevation changes across them. The vertical scale of exaggeration of these profiles was highly exaggerated to help highlight the various geomorphic features. Lineaments were compared to topographic and geologic maps at various scales to ensure that they are not associated with foliation planes, changes in lithology, or glacial landforms. Rose diagrams were also generated for the lineaments interpreted across the Biddeford and Agamenticus plutons of southern Maine using the stereonet programs of Allmendinger et al. (2013) and Cardozo and Allmendinger (2013). Some of the more prominent linear depressions and scarps were then field checked to visualize them on the ground and to look for evidence of faulting on them, such as slickensides, breccia, and offset bedrock units. Abbreviations of the various faults, lineaments, scarps, and topographic depressions and highs are summarized in Tables A1 and A2 in the Appendix. 


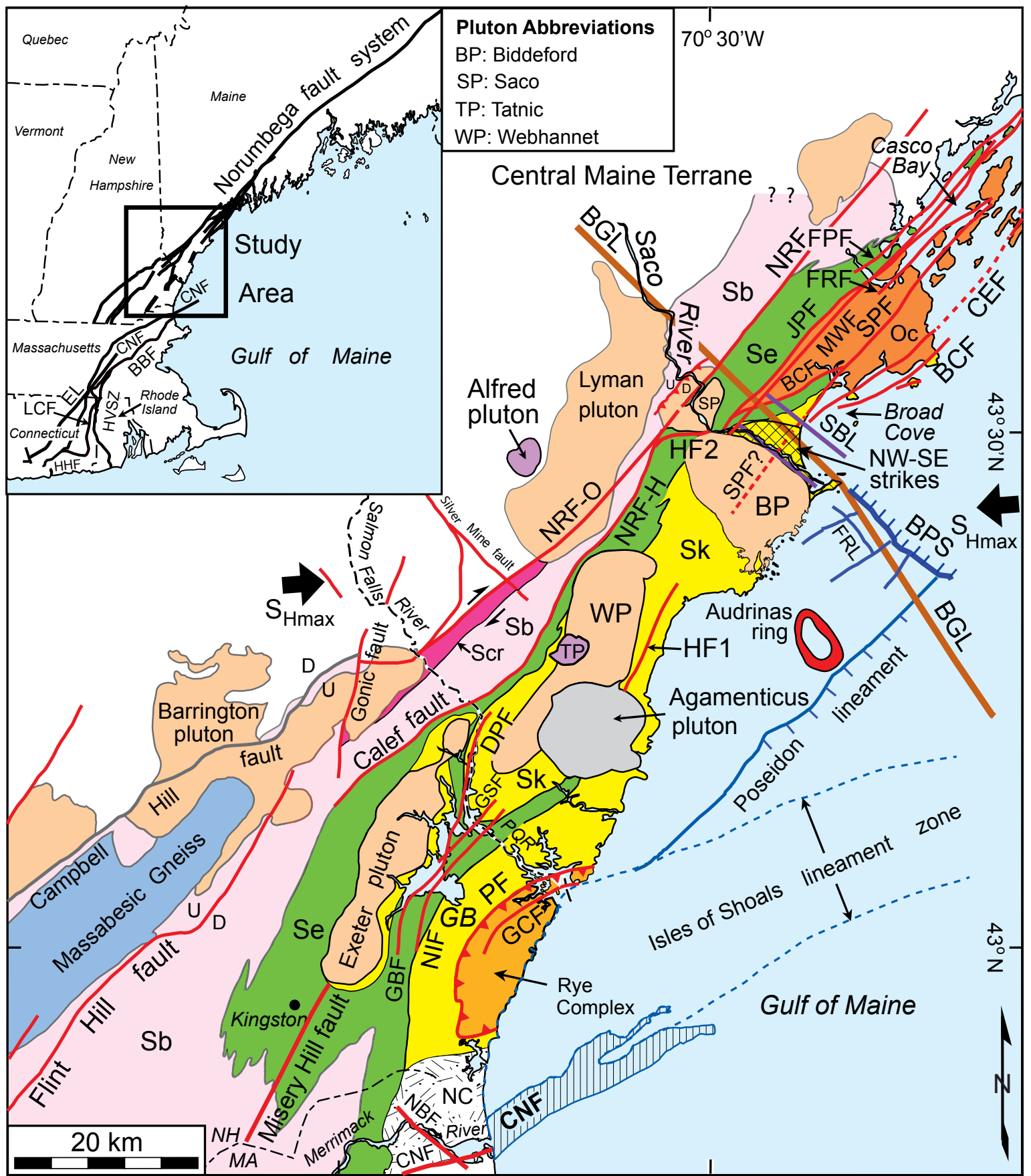

Figure 1. Summary geological map of the southwestern part of the Norumbega fault system. Paleozoic (tan), Triassic (grey), and Cretaceous (purple) plutons are from Osberg et al. (1985) and Lyons et al. (1997). Faults (red lines, dashed where inferred) are from Osberg et al. (1985), Hussey (2003a-d), Hussey et al. (2016), and Lyons et al. (1997). The Biddeford linear gravity anomaly (BGL, brown line) is from figure 32 of Marple et al. (2018a). NBF is from Marple et al. (2018b). The cross-hatch pattern northeast of the Biddeford pluton shows the location of the NW-SE strikes of foliation and bedding of the Merrimack terrane. Patterns labeled Oc, Sb, Se, and Sk are the Casco Bay Group and the Berwick, Eliot, and Kittery formations. NC is the Newburyport igneous complex. SBL (purple line) is the Saco Bay magnetic lineament. The Isles of Shoals lineament zone is from Marple and Hurd (2019). Opposing arrows labeled $S_{\mathrm{H} \max }$ represent the generalized orientation of the horizontal compressive stress field from Zoback and Zoback (1991). GB is the Great Bay estuary and $P Q R$ is the Piscataqua River. Abbreviations for faults, lineaments, scarps, and topographic depressions and highs are listed in Tables $\mathrm{A} 1$ and $\mathrm{A} 2$ in the Appendix. 


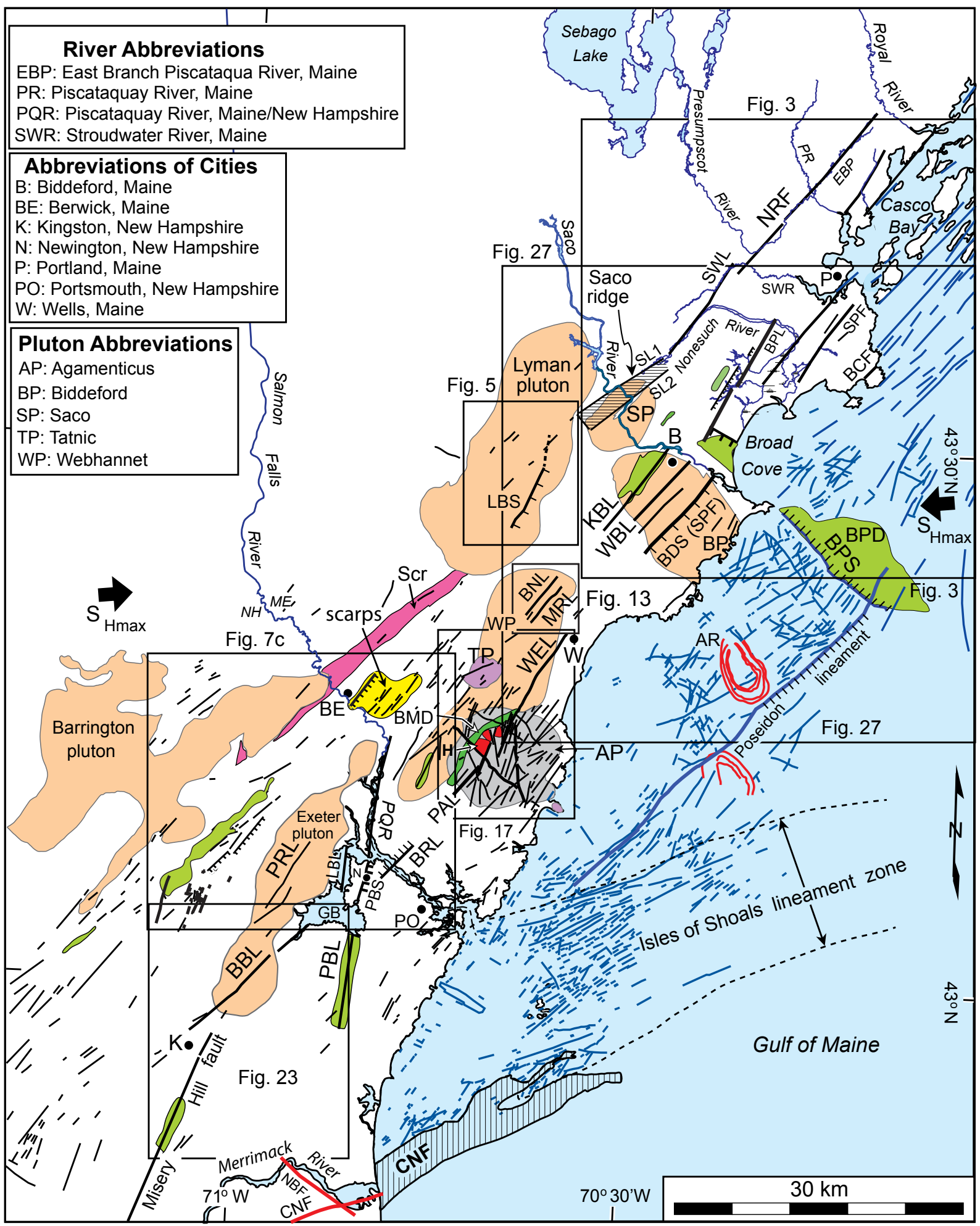

Figure 2. Interpretive map of LiDAR (black lines) and sonar (blue lines) lineaments in the study area from Marple and Hurd (2019). AR is Audrinas ring. Paleozoic (tan), Triassic (grey), and Cretaceous (purple) plutons are from Osberg et al. (1985) and Lyons et al. (1997). Green patterns are linear depressions or valleys. The yellow pattern east of Berwick, Maine, is the area of SE-facing scarps shown in Figures 9 and 10. Abbreviations for faults, lineaments, scarps, and topographic depressions and highs are listed in Tables A1 and A2 in the Appendix. 

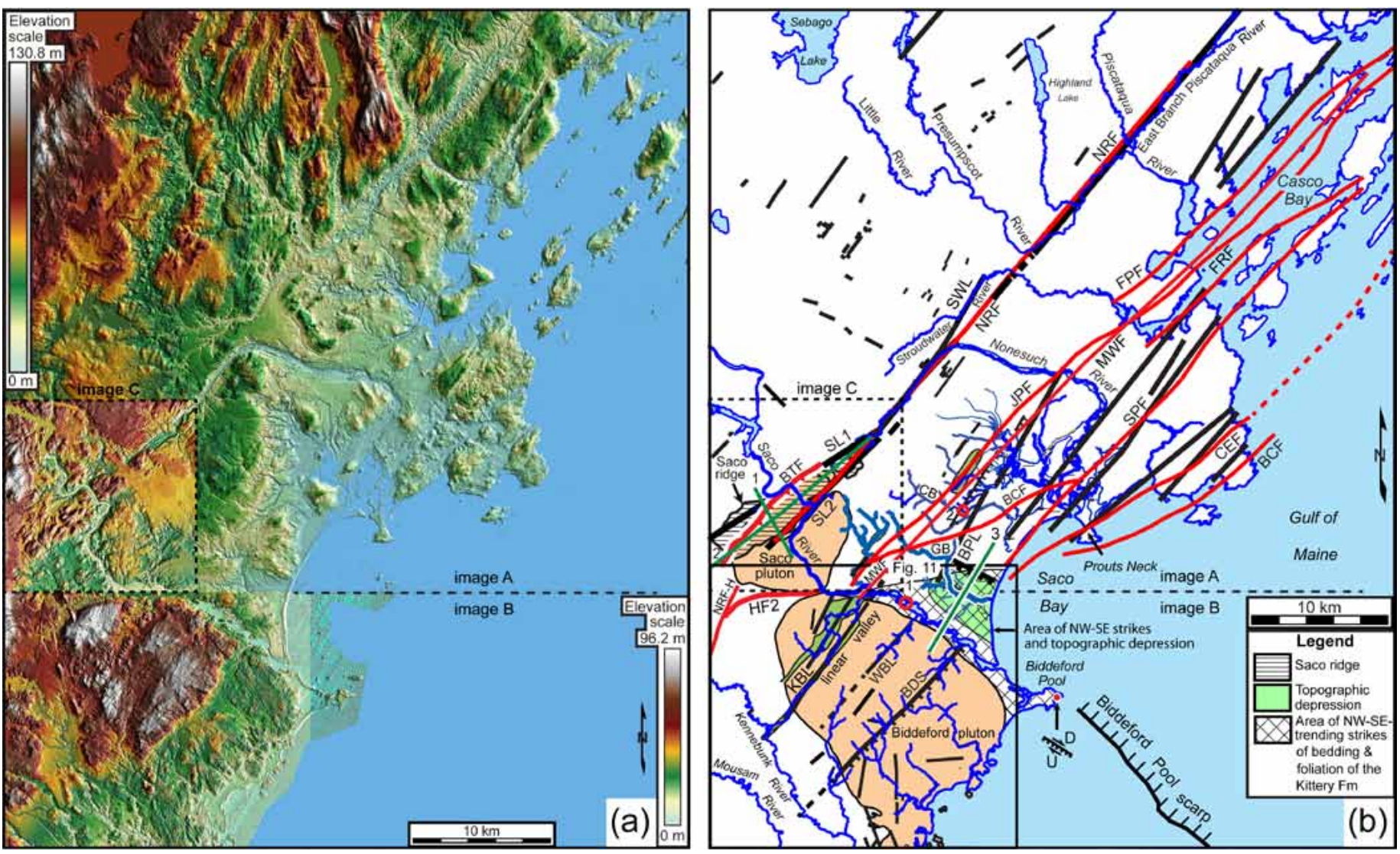

Figure 3. (a) Overlay of three different LiDAR images labeled A, B, and C of the Biddeford and Casco Bay areas showing the continuation of linear depressions and scarps southwest of the Saco River and their parallelism with most of the NFS. The image location is shown on Figure 2. (b) Interpretation of the diagram in (a) showing the near-alignment and parallelism of the LiDAR lineaments (black lines) with mapped NFS faults (red lines) southwest of Casco Bay, as well as several NWSE-trending features that intersect the LiDAR lineaments northeast of the Biddeford pluton. The fault locations are from Hussey (2003a-d) and Marvinney (1995). CB and GB are the Cascade and Goosefare brooks, respectively. The red dot at Biddeford Pool is the location of a NW-SE-oriented dextral-oblique reverse fault first noted by Mark Swanson (personal communication, 2019). Red circles labeled 1 and 2 are water falls along the Saco River and Cascade Brook just upstream from the West Brook (WBL) and Blue Point (BPL) lineaments. The green lines are topographic profiles shown in Figure 4.

\section{GEOLOGIC SETTING OF THE STUDY AREA}

\section{Surficial geology and glacial landforms}

The surficial sediments in the study area are predominantly Pleistocene glacial till, glaciomarine facies, and relatively thin Holocene fluvial deposits (e.g., Thompson and Borns 1985). The till consists of poorly sorted gravel, sand, silt, and clay. The glaciomarine facies generally consist of laminated pebbly mud, coarse-grained ice-rafted debris, gravelly sandy mud, and clayey silts (Thompson and Borns 1985).

The most common glacial landforms in the study area are drumlins, end moraines, and eskers. The up-ice side of drumlins is typically steep while the down-ice side is smooth and tapers gently in the direction of ice movement
(Thompson and Born 1985). The orientations of the drumlins and end moraines indicate that the Laurentide ice sheet moved southeastward across the study area.

\section{Terranes and plutons}

The main geological terranes southwest of Casco Bay are the NE-SW-trending Central Maine and Merrimack terranes and the Casco Bay Group (Fig. 1). They consist primarily of metamorphosed shale, siltstone, and sandstone that accumulated in two ancient ocean basins, the Central Maine Basin to the west and the Merribuckfred Basin to the east (Hussey et al. 2010). The Early Silurian or Late Ordovician Eliot and Kittery formations form most of the Merrimack terrane in the study area and the Silurian Berwick 
Formation forms the eastern side of the Central Maine Basin (Fig. 1). The Eliot Formation consists of thin-bedded medium buff to grey-weathering calcareous metasiltstone and dark grey slate or phyllite and the Kittery Formation consists of a thin- to thick-bedded sequence of fine-grained calcareous and feldspathic metawacke and lesser metashale (Hussey et al. 2016). The Middle to Late Ordovician Casco Bay Group, northeast of the Kittery Formation, consists of phyllite, schist, granofels, amphibolite, marble, and gneiss (Berry and Hussey 1998). The Berwick Formation to the west consists of an interbedded sequence of calcareous and non-calcareous feldspathic metawacke with minor biotiterich schist (Hussey et al. 2016).

These terranes were intruded by Early Devonian to Cretaceous plutons that vary in size and shape (Hussey et al. 2016; Lyons et al. 1997) (Fig. 1). Except for the NW-SEoriented Biddeford pluton, most of the Paleozoic plutons in the study area are elongate in a NE-SW direction. The Mesozoic plutons, in contrast, are roughly circular in map view. Because the plutons are more resistant to erosion than the surrounding terranes, they tend to form areas of higher terrain where the glacial and glaciomarine sediments are thinner. Consequently, geomorphic lineaments are more numerous and conspicuous across the plutons.

\section{LIDAR OBSERVATIONS}

Because the LiDAR images revealed numerous lineaments, only the most prominent lineaments are described here along the southwest projections of the Nonesuch River (NRF), Mackworth (MWF), and South Portland (SPF) faults. Except for the ENE-WSW-trending Broad Cove fault, most of the lineaments between Casco Bay and the Saco River coincide with or are nearly parallel to faults of the NFS (Fig. 3). These lineaments are characterized by linear depressions, straight stream segments, and $\sim 90^{\circ}$ bends in rivers (Fig. 3).

\section{Lineaments along the trend of the NRF}

West of Casco Bay, the NRF coincides with linear NE-SWtrending segments of the Presumpscot River and the East Branch of the Piscatiqua River (Fig. 3). The next segment of the NRF to the southwest coincides with a lineament, herein named the Stroudwater lineament, that is formed by straight stream segments of the Stroudwater and Nonesuch rivers. The Stroudwater lineament is offset to the northwest $\sim 2 \mathrm{~km}$ from the NRF to the northeast (Fig. 3). To the southwest, the Stroudwater lineament is collinear with lineaments SL1 and SL2 where they cross the Saco pluton and Berwick Formation (Fig. 3b). Here SL1 forms a $\sim 14^{\circ}$ counterclockwise (CCW) bend with the Stroudwater lineament (Fig. 3). SL1 and SL2 also bound a linear, $\sim 2-\mathrm{km}$-wide, 10-km-long, NE-SWoriented 30-m-high area, here named Saco ridge, between the two $90^{\circ}$ bends in the Saco River (Figs. $3 \mathrm{~b}$ and 4, profiles 1 and 2). SL2 coincides with the NRF and SL1 occurs near an unnamed southeast-dipping, NE-SW-oriented thrust fault of Berry and Hussey (1998) (Fig. 3b).

Approximately $3 \mathrm{~km}$ southwest of Saco ridge and along the NRF trend is the $\sim 12-\mathrm{km}$-long, $40-\mathrm{m}$-high, NE-SWtrending, east-facing Lords Brook scarp that crosses the Lyman pluton at an angle of $\sim 17^{\circ} \mathrm{CCW}$ to the general trend of the NRF to the northeast (Figs. 2, 5, and 6). The scarp is also highlighted on surficial geologic maps by a change from mostly glacial till above (west of) the scarp to glaciomarine sediments at the lower elevations east of the scarp (Fig. 5b).

Approximately $20 \mathrm{~km}$ southwest of Lords Brook scarp and collinear with the NRF is a $3-$ to $4-\mathrm{km}$-wide, $40-\mathrm{km}$ long zone of NE-SW-trending lineaments (Figs. 7a and $7 b$ ). Some of the linear depressions disrupt the otherwise streamlined appearance of the NW-SE-oriented drumlins in the northeastern part of this zone. These linear depressions coincide with the base of gentle SE-facing scarps that have as much as $15 \mathrm{~m}$ of relief where they cross drumlins (Figs. $8-10)$. The crests of some of these scarps coincide with linear ridges that are up to $10 \mathrm{~m}$ above the surrounding terrain (e.g., Figs. 9a and 10, profiles 1, 3, and 4). The zone of lineaments southwest of the Salmon Falls River coincides with a 1- to 3-km-wide, 10- to 25-m-deep depression, east of which is a SE-facing, 40 -m-high scarp (Fig. 8, profiles 1 and 2). The southwestern end of this zone coincides with the Calef/Nonesuch River fault of Hussey et al. (2016) (Fig. 7b).

\section{Lineaments along the southwest projection of the MWF}

Along the southwest projection of the MWF (Fig. 3) is a conspicuous, $\sim 400$-m-wide, $\sim 10$-m-deep linear depression that defines the Kennebunk lineament where it crosses the Biddeford pluton and adjacent Kittery Formation (Figs. 11a and 12). The southwestern end of the Kennebunk lineament coincides with a 500-m-wide right-lateral deflection in the Kennebunk River where it crosses the Kittery Formation (Fig. 11b). The NE-SW lineament trend in the rose diagram of the Biddeford pluton parallels the trend of the Kennebunk lineament and other NE-SW-trending lineaments crossing the pluton (Fig. 11b).

Approximately $10 \mathrm{~km}$ southwest of the Biddeford pluton are two parallel lineaments that are collinear with the Kennebunk lineament where they cross the Webhannet pluton (Fig. 2). The 5-km-long Merriland River lineament is defined by the alignment of the $90^{\circ}$ bend in the Merriland River with the Town Woods Brook (Fig. 13) along the Mackworth fault trend. The area west of the river bend is up to $20 \mathrm{~m}$ higher than the area to the east (Fig. 14). This area, like that west of the Lords Brook scarp (Fig. 5b), is capped by till deposits whereas the topographically lower area to the east is covered by glaciomarine deposits (Fig. 13b). A second, less conspicuous lineament to the northwest (Burnt Road lineament) is formed by the alignment of a Merriland 

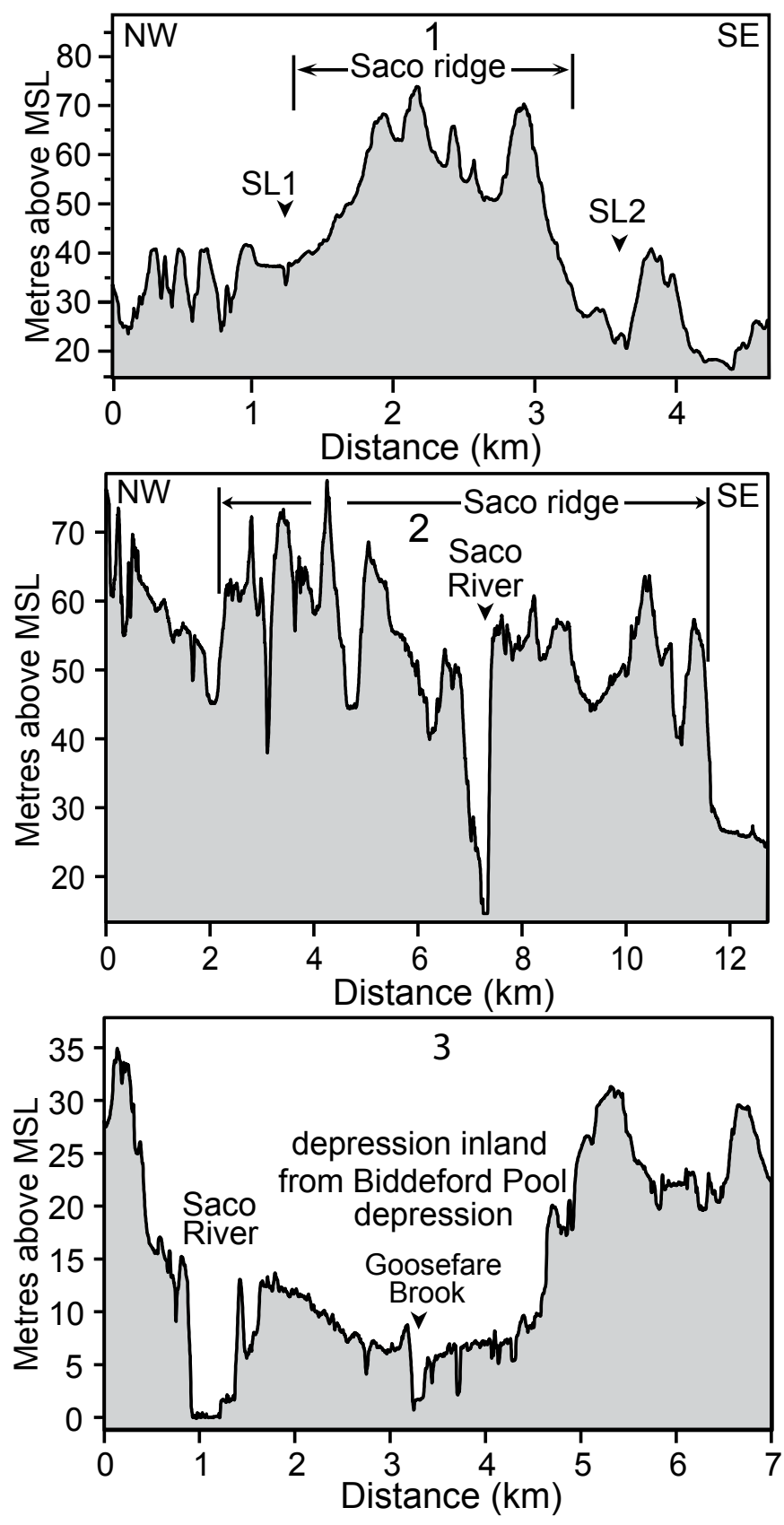

Figure 4. Topographic profiles showing the elevated terrain across Saco ridge between lineaments SL1 and SL2 (profiles 1 and 2) and the depression inland from the Biddeford Pool depression (profile 3). Profile locations are shown in Figure $3 \mathrm{~b}$.

River tributary with a NE-SW-trending, 2- to 4-m-deep linear depression to the northeast (Fig. 13). In contrast to the areas underlain by the Biddeford and Webhannet plutons, few lineaments were observed in the topographically lower area underlain by the Merrimack terrane between these two plutons where the glaciomarine sediments are up to $70 \mathrm{feet}$ (21.3 m) thick (Smith 1998).
The 15-km-long, NE-SW-oriented Piscassic River lineament is approximately $30 \mathrm{~km}$ to the southwest along a similar trend (Fig. 15). It crosses the Exeter pluton northwest of Great Bay and is defined by a linear, 18-m-deep valley to the northeast and a linear river drainage pattern to the southwest (Figs. 15 and 16).

\section{Lineaments along the southwest projection of the SPF}

The most prominent lineament along the southwest projection of the SPF is the 30-m-high, $\sim 10-\mathrm{km}$-long, southeast-facing Biddeford scarp where it crosses the Biddeford pluton (Figs. 11 and 12). Along the base of the scarp is a subtle $0.5-$ to $1-\mathrm{km}$-wide, 5 - to 8 -m deep depression (Fig. 12). The lineament continues another $4 \mathrm{~km}$ to the southwest across glaciomarine sediments underlain by the Kittery Formation where there is an abrupt increase in the sinuosity of the Kennebunk River downstream from this trend (Fig. 11b). Upstream from this trend, the channel is entrenched 3-4 m more than that downstream.

Approximately $10 \mathrm{~km}$ to the southwest and collinear with the Biddeford scarp is the Wells lineament, which is defined by the abrupt termination of a drumlin, linear depressions up to $8 \mathrm{~m}$ deep, and $90^{\circ}$ bends in Green Brook, Depot Brook, and Pope Creek (Figs. 17b, 18, profile 4, and 19). The lineament is better defined across the Webhannet pluton than across the Kittery Formation to the northeast where the sediments are thicker (Fig. 17b). Approximately $600 \mathrm{~m}$ southeast of and parallel to the Wells lineament is the $\sim 2-\mathrm{km}$-long Webhannet River lineament, southwest of which is a rectilinear drainage pattern formed by several NE-SW-trending stream segments of the Webhannet River (Fig. 19). Approximately 400 to $600 \mathrm{~m}$ southeast of the Wells lineament and nearly coincident with the Webhannet River lineament is the $\sim 11 \mathrm{~km}$ long, NE-SW-trending Wells magnetic lineament interpreted from Daniels and Snyder (2004) (Fig. 17b).

Continuing southwest across the Agamenticus pluton, the Wells lineament is collinear with both a curved, NNESSW-trending valley, here named the Bell Marsh depression (BMD), and a 1- to 1.5-km-wide zone of NNE-SSW-trending linear depressions to the east, here named the Third Hill zone of linear depressions (THZ) (Fig. 17b). The BMD is a 1.5- to 2-km-wide, 20- to 60-m-deep curved valley, part of which is dammed to form the Bell Marsh Reservoir (Figs. $17 \mathrm{a}$ and 18 , profiles 5,7 , and 8 ). The BMD crosses alkali granite (unit Trg) along the west side of the pluton and the Kittery Formation to the south (Figs. 17b and 20). Along the east side of the BMD are three, 80- to 120-m-high areas known as Mount Agamenticus, Second Hill, and Third Hill that are also mostly underlain by unit Trg (Figs. 17b and 18 , profiles 7 and 9). The southwestern end of the BMD is bounded by three distinct lineaments: the $\sim 3$-km-long York Woods lineament that coincides with a 30-m-high, eastfacing scarp that crosses the Webhannet pluton, the curved 

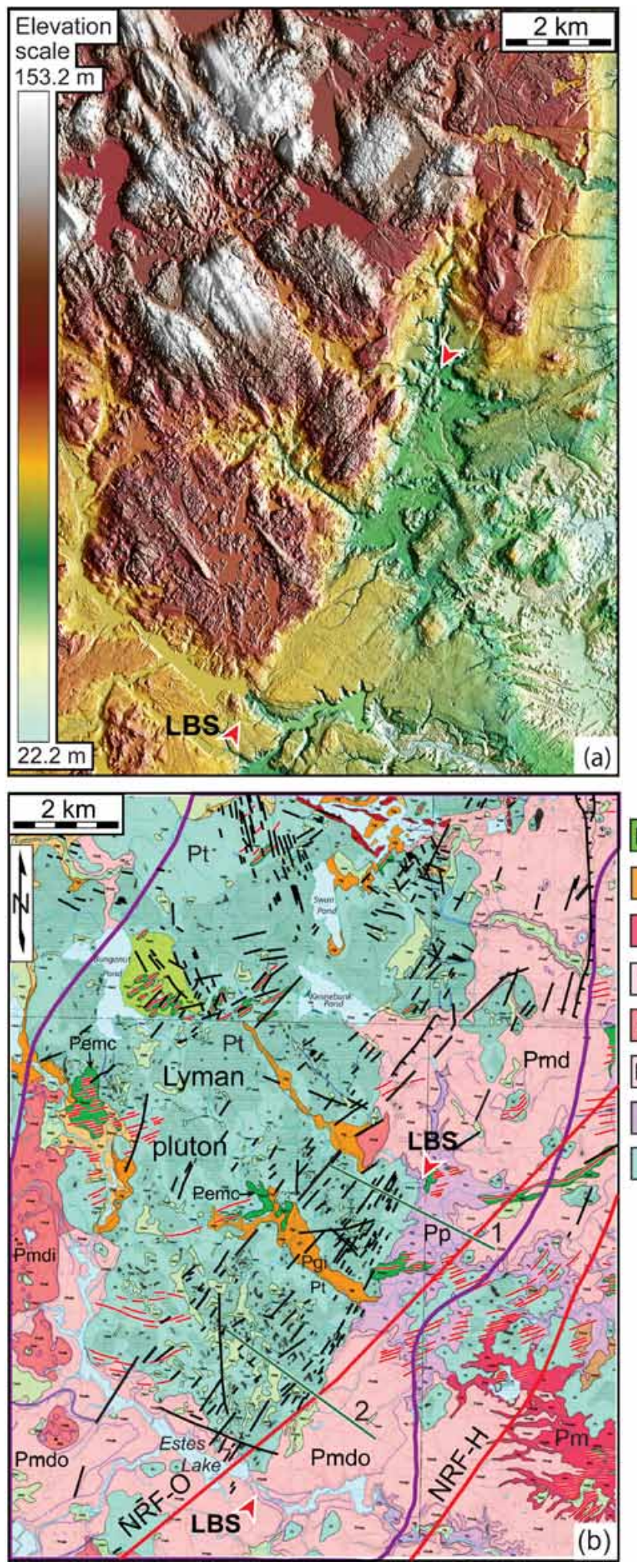

\section{LEGEND}

Pemc end moraine complex

Pgi ice contact deposits

Pgi (coarse gravel and sand)

$\mathrm{Pm}$ marine deposits

Pmd marine delta

Pmdi head of marine delta

Pmdo distal portion of marine delta

$\mathrm{Pp}$ Presumpcot Formation (silt and silty clay)

Pt till (poorly sorted mixture of silt, sand, pebbles, cobbles, and boulders)

end moraines

$\geqslant$

LiDAR

lineament

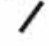

bedrock exposed or $<2 \mathrm{~m}$

beneath surficial sediments

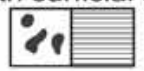

Figure 5. (a) LiDAR image of the Lords Brook scarp (LBS) along the trend of the NRF. Image location is shown on Figure 2. (b) Interpretation of diagram (a) overlain on the surficial geology of Hunter (1999), Meglioli (1999), Neil (1999) and Smith (1999b) to show that the west (elevated) side of the LBS is underlain by till deposits and that it cuts across the Lyman pluton (between purple contours). The black lines are interpreted LiDAR lineaments and the red lines are faults. The green lines are the locations of topographic profiles in Figure 6. Abbreviations for faults, lineaments, and topographic scarps and depressions are listed in Tables A1 and A2 in the Appendix. 


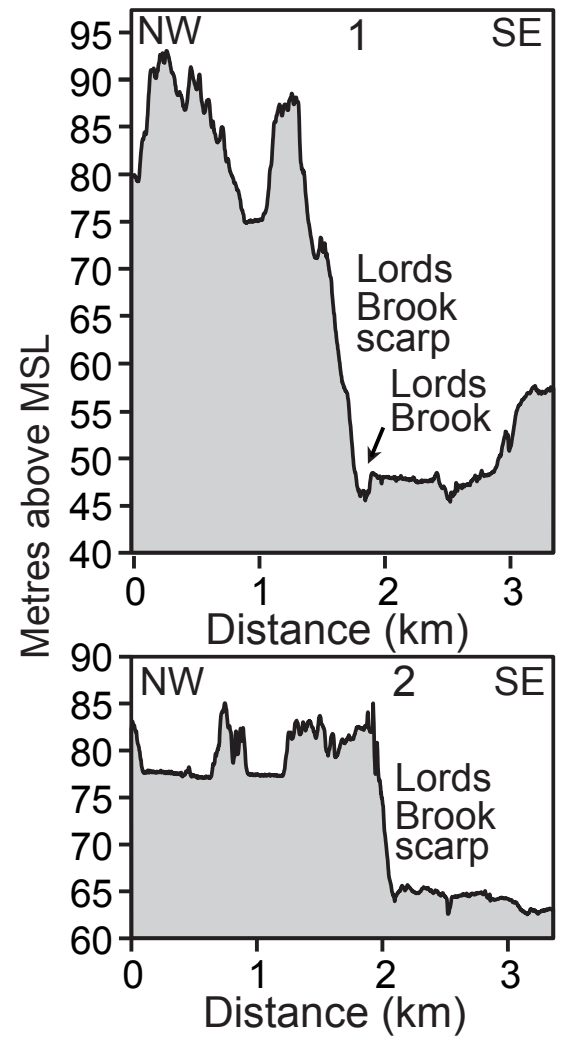

Figure 6. Topographic profiles across Lords Brook scarp. Profile locations are shown in Figure 5b.

Bell Marsh lineament that coincides with a 50-m-high, west-facing scarp that crosses the Agamenticus pluton, and the Berwick lineament at the southernmost end of the BMD that coincides with a steep 40 -m-high, west-facing scarp that crosses the Agamenticus pluton and Kittery Formation (Figs. 17b, 18, profiles 5 and 8 , and 21 ).

The THZ consists of numerous linear depressions, some of which are as deep as $14 \mathrm{~m}$. Approximately $1 \mathrm{~km}$ west of and parallel to the THZ, the 9-km-long Folly Pond lineament is associated with a linear depression up to $25 \mathrm{~m}$ deep (Figs. 17 and 18, profiles 2 and 8 ). The THZ and Folly Pond lineament trend $21^{\circ}$ more northerly than the NE-SW-trending linear depressions southwest of the NW-SE-trending Chases Pond lineament, the most prominent of which is the Payneton lineament (Fig. 17). The Payneton lineament, which crosses both the Kittery Formation and the Agamenticus pluton, coincides with a linear valley that is up to $25 \mathrm{~m}$ deep (Fig. 18, profile 2). The southwestern end of the Payneton lineament coincides with a steep (northeastern end) to gently sloping (southwestern end), 700-m-long, northwest-facing scarp that is up to $27 \mathrm{~m}$ high to the northeast where it crosses the Kittery Formation (Figs. 18, profile 3, and 20). There are several near-vertical, 5- to 10 - $\mathrm{ft}$-high $(\sim 2-3 \mathrm{~m})$ rock faces along the northeastern end of the scarp. The interpreted southern edge of the contact metamorphic aureole in the
Kittery Formation is dextrally offset $300-500 \mathrm{~m}$ along this scarp (Fig. 20). The Payneton lineament abruptly terminates to the northeast along the Folly Pond lineament (Fig. 17). Near the southwestern end of the Payneton lineament are several near-vertical, 3- to 4-m-high rock faces in the Kittery Formation on both sides of the valley along the lineament. Other less prominent linear depressions, such as the Berwick and MacIntire Garrison lineaments, parallel the Payneton lineament (Fig. 17b). The southwestern end of the Berwick lineament forms a $\sim 35$-m-high, west-facing scarp in the Kittery Formation where it forms the southeastern wall of the southernmost BMD (Figs. 17 and 18, profile 5). Between the BMD and Payneton lineament are several NE$\mathrm{SW}$-trending lineaments along which segments of the NWSE-trending Horse Hills lineament are dextrally offset 30 to $80 \mathrm{~m}$ where it crosses the Agamenticus pluton (Fig. 22).

In contrast to the Agamenticus pluton, few lineaments were identified immediately to the southwest where several large drumlins and thick glaciomarine sediments obscure most of the underlying Merrimack terrane (Thompson and Borns 1985) (Fig. 2). However, along the southwest projection of the Payneton lineament and crossing the Piscataqua River is a NE-SW-trending, 500-m-wide, 15- to 30-m-deep depression and a gentle NW-facing, 15-m-high gentle scarp that form the Beech Road lineament (Figs. 7b and 8 , profiles 3 and 4 ). The depression coincides with the northeastern end of the Nannie Island fault (Figs. 7b and 8). To the southwest and along the northern edge of Great Bay are several NE-SW-trending linear ridges and depressions and a rectilinear type drainage pattern (Fig. $7 \mathrm{~b}$ ) that are collinear with the Beech Road lineament.

Southwest of the Great Bay estuary, the $\sim 23-\mathrm{km}$-long, NE-SW-trending Bloody Brook lineament coincides with part of the Bloody Brook valley (Figs. 23 and 24, profile 1) and the abrupt termination of a drumlin to the southwest where it crosses the Exeter pluton and Eliot Formation (Fig. $23)$. The Bloody Brook lineament is offset $\sim 1.5 \mathrm{~km}$ across the Great Bay estuary in a right-step direction from the trend of the Beech Road lineament to the northeast (Fig. 2). It continues northeast of Bloody Brook along the NESW-trending segment of the Squamscott River, but with a $\sim 400$-m-wide, right-step offset along the NW-SE-trending Stratham lineament near an abrupt southward bend in the Squamscott River (Fig. 23b).

The southern end of the Bloody Brook lineament intersects a NNE-SSW-oriented lineament associated with the Misery Hill fault at an angle of $\sim 15^{\circ}$ (Fig. 23). The northeast end of this lineament is defined by a $2.5-\mathrm{km}$-long, 10- to 15-m-high, NW-facing scarp and a 1.2-km-long, 15to 20-m-high, NE-SW-trending ridge where it crosses the Exeter pluton and Eliot Formation (Fig. 24, profiles 2-3). To the southwest it coincides with a 1.5 - to $2-\mathrm{km}$-wide, 15-m-deep linear valley (Fig. 24, profile 4) where it crosses the Eliot Formation (Fig. 23b). 

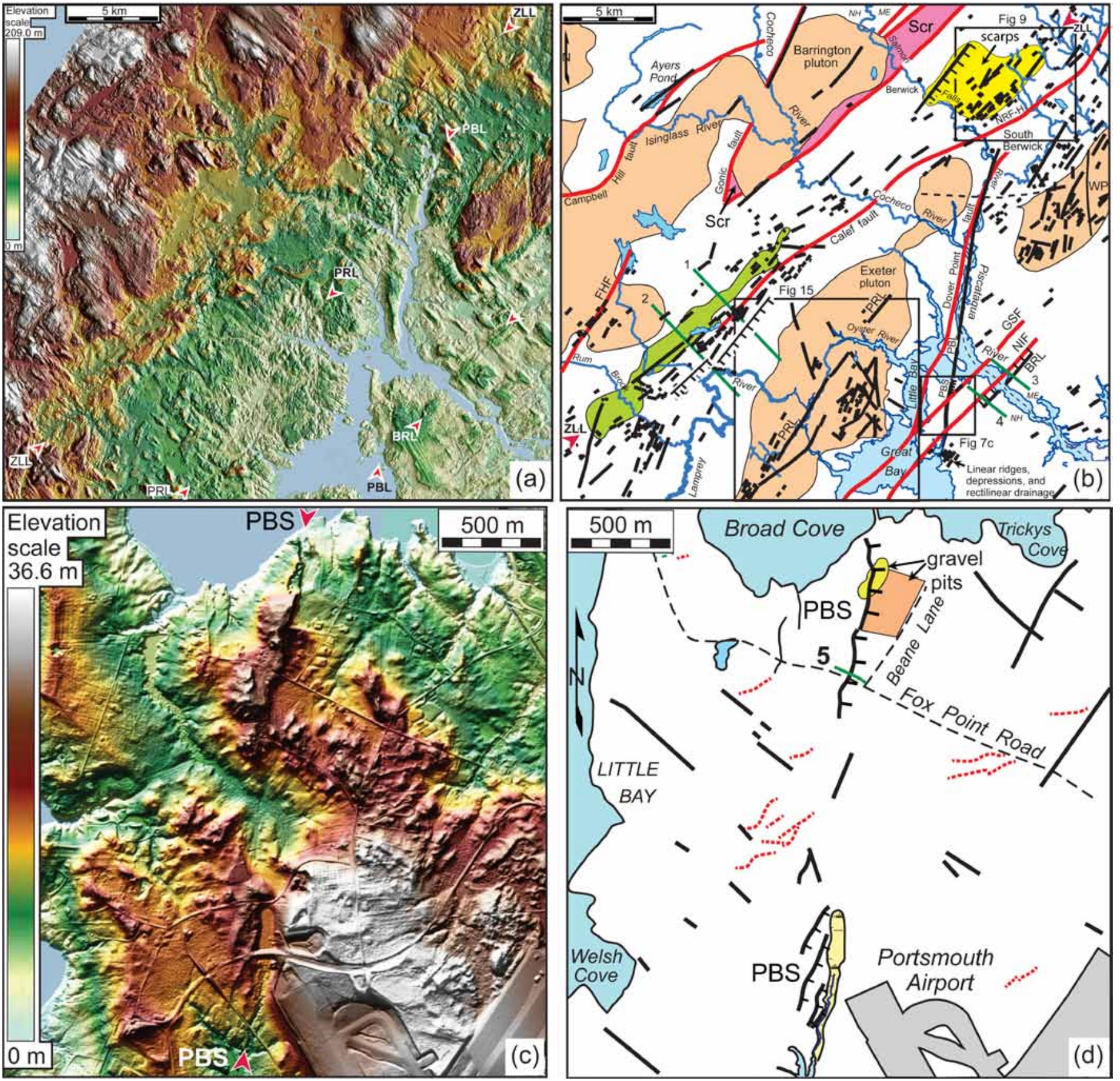

Figure 7. (a) LiDAR image of the area north of the Great Bay estuary showing the continuation of lineaments to the southwest, including the zone of LiDAR lineaments (ZLL), Piscassic River (PRL) and Beech Road (BRL) lineaments, and a portion of the Peverly Brook lineament (PBL). Image location is shown on Figure 2. (b) Interpretation of the diagram in (a). The tan areas are plutons of Hussey et al. (2016) and Lyons et al. (1997). WP is the Webhannet pluton. The black lines are LiDAR lineaments and the red lines are faults from Hussey et al. (2016) and Lyons et al. (1997). The green lines are the locations of topographic profiles shown in Figure 8. The green pattern is a linear depression along the southwest continuation of the NRF. Lines with ticks (down side) are scarps. The yellow pattern is the area of down-to-the-SE scarps shown in Figures 9 and 10. Abbreviations for faults, lineaments, and scarps are listed in Tables A1and A2 in the Appendix. (c) Enlarged LiDAR image of the Peverly Brook scarp (PBS). Location is shown in diagram (b). (d) Interpreted map of diagram (c). The green line labeled 5 is an elevation profile shown in Figure 8. 

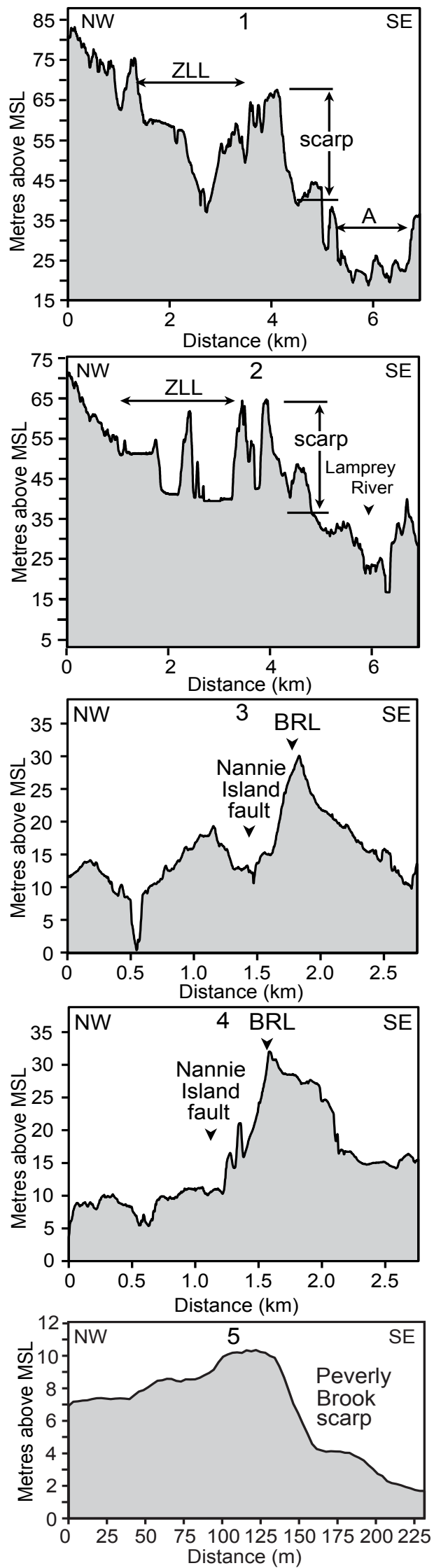

\section{NW-SE- and ENE-WSW-trending lineaments crossing the Agamenticus pluton}

In contrast to other plutons, several prominent NW-SEtrending linear depressions and valleys, some of which are dammed to form man-made lakes, cross the Agamenticus pluton (Figs. 17b and 21). Some of these linear, canyonlike valleys are up to $50 \mathrm{~m}$ deep, such as the Chases Pond lineament (Fig. 18, profile 6), and form anomalous patterns across the Agamenticus pluton, such as the triangularshaped area between the Groundnut Hill and Chases Pond lineaments that is up to $30 \mathrm{~m}$ higher than the surrounding terrain (Figs. 17a and 18, profile 1). Another anomalous observation is the abrupt increase in elevation north of the Chases Pond lineament and west of the Folly Pond lineament and southern end of the THZ without a change in bedrock type (Figs. 17 and 18, profile 9).

Lineaments trending ENE-WSW also occur toward the eastern side of the Agamenticus pluton (Fig. 21). One of these lineaments, the Agamenticus Village lineament, coincides with a 13-m-high, SE-facing scarp across a previously unmapped drumlin, here named the Old Mountain Road drumlin (Figs. 25 and 26).

\section{Peverly Brook and Little Bay lineaments}

The 30-km-long, NNE-SSW-oriented Peverly Brook lineament (Marple et al. 2015) crosses the general NESW trend of lineaments and faults in southeastern New Hampshire (Fig. 2). It is defined by the alignment of the Winnicut River valley south of Great Bay, the Peverly Brook drainage north of Great Bay, and the NNE-SSW-trending reach of the Piscataqua River north of Little Bay (fig. 7 of Marple and Hurd 2019). The PBL also coincides with part of the Dover Point fault (Fig. 1) along the Piscataqua River north of Little Bay. Near Newington, New Hampshire, the Peverly Brook lineament coincides with a few 3- to 4-m-high, east-facing en échelon scarps (Figs. 7c, 7d, and 8, profile 5) that are formed in Pleistocene sediments (Marple et al. 2015).

The north-south orientation of Little Bay north of Great Bay is nearly parallel to the Peverly Brook lineament and is here named Little Bay lineament. Like the Peverly Brook lineament, the Little Bay lineament cuts across the dominant NE-SW trend of lineaments in southeastern New Hampshire. Part of the Dover Point fault coincides with the east side of Little Bay (Fig. 1).

Figure 8. (left) Topographic profiles showing the coincidence of the zone of LiDAR lineaments (ZLL) with SEfacing scarps east of Berwick, Maine, the Beech Road lineament (BRL) defined by NW-facing scarps and linear depressions along the southwest projection of the SPF, and the east-facing PBS. Profile locations are shown in Figures $7 \mathrm{~b}$ and $7 \mathrm{~d}$. 

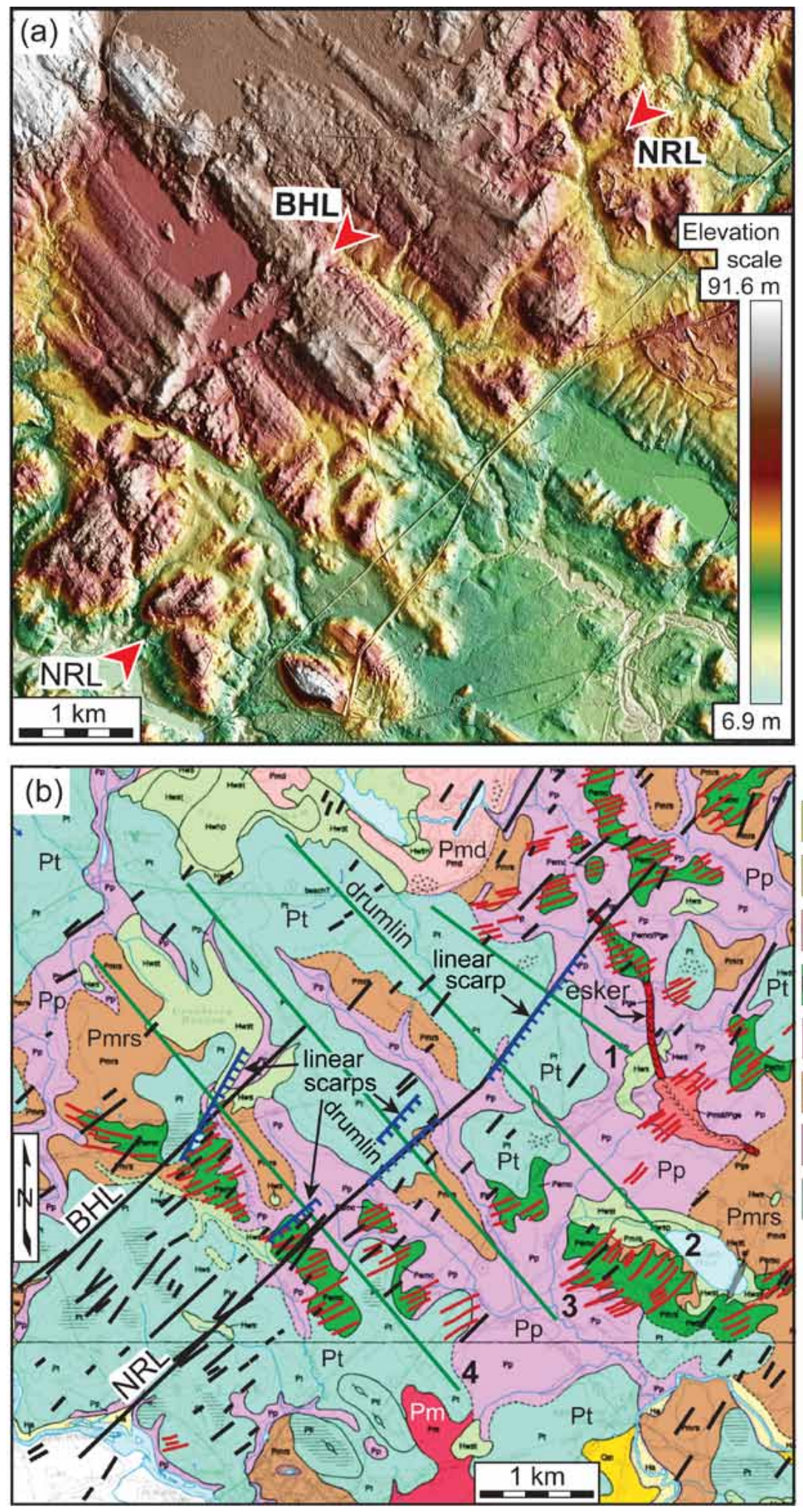

\section{LEGEND}

Hws swamp

Hwst stream terrace

Pmd marine delta

Pemc end moraine complex

Pm marine deposits

Pmrs regressive marine sand deposits

Pp Presumpcot Fm (silt and silty clay)

$\mathrm{Pt}$ till (poorly sorted mixture of silt, sand, pebbles, cobbles, and boulders)<smiles>C=C</smiles>

linear scarps

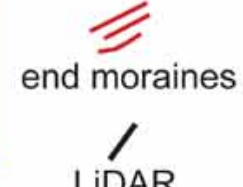

LiDAR

lineament

Figure 9. (a) Enlarged LiDAR image east of Berwick, Maine, showing linear depressions and SE-facing scarps that interrupt the NW-SE-trending drumlins along the southwest projection of the NRF. Image location is shown Figure $7 \mathrm{~b}$. (b) Interpretation of diagram (a) overlain on the surficial geology of Smith (1999a, 1999d) to show that these scarps (ticks on the down side) are formed in till (drumlin) deposits. The green lines are the locations of topographic profiles shown in Figure 10. Lineament abbreviations are listed in Table A2 in the Appendix. 

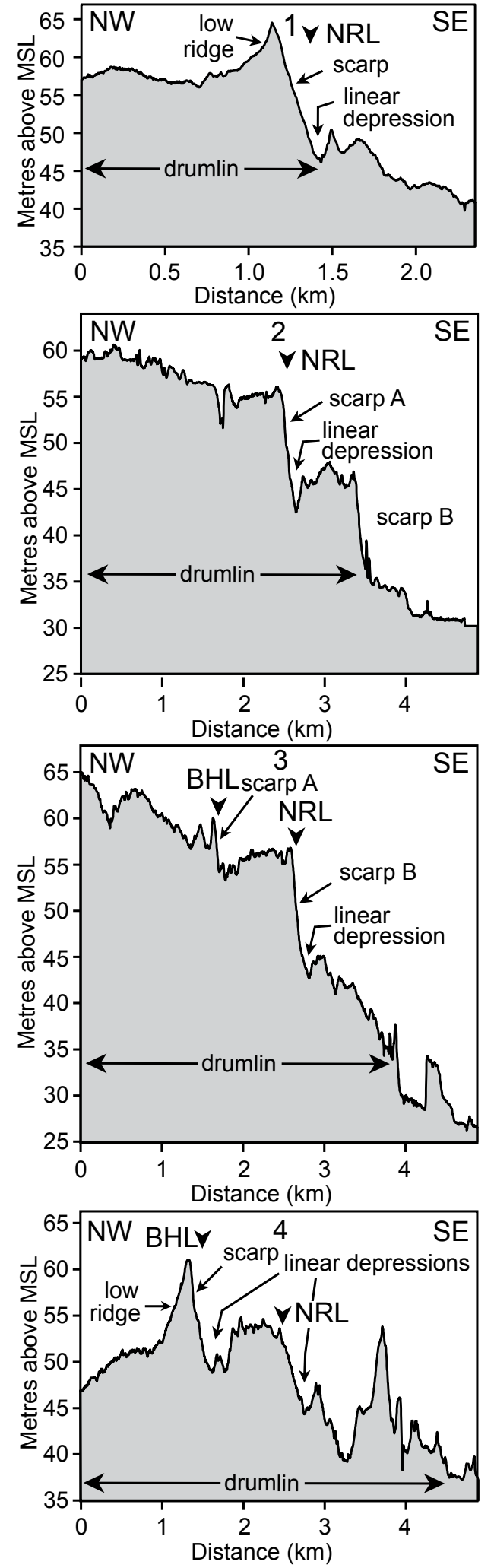

Figure 10. Topographic profiles showing SE-facing scarps that cross drumlins and linear depressions along the base of these scarps. Profile locations are shown in Figure $9 b$.

\section{EVIDENCE FOR A NW-SE-TRENDING STRUCTURE NEAR BIDDEFORD, MAINE}

\section{Aeromagnetic lineaments near Biddeford, Maine}

The aeromagnetic anomaly map of the Biddeford, Maine, area from Daniels and Snyder (2004) reveals several NESW-trending linear positive magnetic anomalies northeast of the Saco River that parallel or coincide with LiDAR lineaments and faults of the NFS (Fig. 27). Near Saco Bay, the NE-SW-trending magnetic lineaments terminate abruptly along NW-SE-trending magnetic lineaments, including the Saco Bay magnetic lineament, that coincide with the area of anomalous NW-SE-trending strikes of bedding and foliation of the Kittery Formation and other NW-SE-trending features near Biddeford Pool (Figs. 1 and 27b). The NW-SE-trending magnetic lineaments also parallel the Biddeford Pool scarp and depression offshore (Fig. 27b). The Biddeford Pool depression is collinear with a 6-km-long, 2.5-km-wide, 25-m-deep depression onshore northeast of the Saco River (Figs. 3b and 4, profile 3).

\section{NW-SE-trending dextral-oblique brittle reverse fault at Biddeford Pool}

Near the trend of the Biddeford Pool scarp at Biddeford Pool, Maine, is a NW-SE-oriented $\left(\sim \mathrm{N} 63^{\circ} \mathrm{W}\right)$ dextraloblique reverse brittle fault dipping $\sim 73^{\circ} \mathrm{SW}$ in the Kittery Formation (Figs. 3b and 28). A slickenside on the footwall has a rake of $68^{\circ} \mathrm{SE}$, indicating a small component of dextral motion, which is opposite the sinistral motion expected based on the current stress field orientation (Fig. 29). The dextral motion is confirmed by a 3- to 4 -m-size dextral displacement of a subunit within the Kittery Formation along this fault (Fig. 28). The amount of reverse displacement is not known. A 0.5- to 1-m-thick Triassic dike cuts across the fault, indicating that it is pre-Triassic. A second, steeply dipping NW-SE-trending brittle fault occurs nearby, although the amount and style of displacement could not be determined.

\section{DISCUSSION}

\section{Origin of the LiDAR lineaments}

Although glacial features are common throughout the study area, they do not appear to be related to the LiDAR lineaments. The end moraines, for example, are relatively short, low-lying $(<5 \mathrm{~m}$ high $)$ ridges that are generally oblique to the much longer LiDAR lineaments (e.g., Figs. 13 and 15). The lineaments, in contrast, are associated with linear depressions and scarps. Nor are the scarps along the lineaments landslide-related because the head scarps 

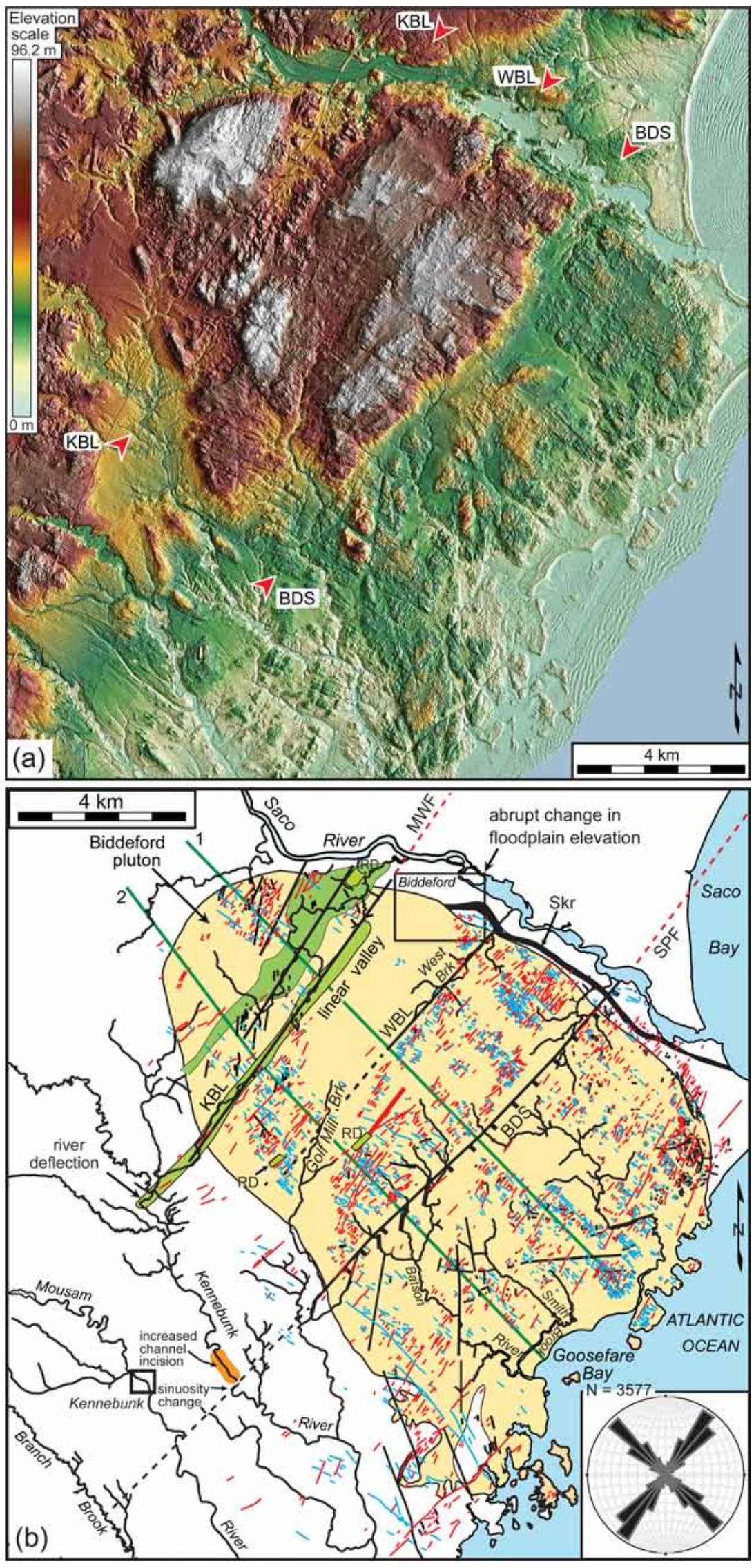
Figure 11. (previous) (a) Enlarged LiDAR image showing the southwest continuation of several prominent linear depressions and scarps across the Biddeford pluton, including the Biddeford scarp (BDS) and the Kennebunk (KBL) and West Brook (WBL) lineaments. Image location is shown in Figure 3b. (b) Interpretation of diagram (a) showing the two dominant NW-SE (green lines) and NE-SW (red lines) trends of shorter LiDAR lineaments, as well as the prominent linear valleys (green patterns) and east-facing scarps that form the KBL, WBL, and BDS. The rose diagram shows the two dominant trends of LiDAR lineaments across the pluton. The black lines are LiDAR lineaments trending in other directions (dashed where inferred). The red dashed lines are the approximated southwest projections of the South Portland (SPF) and Mackworth (MWF) faults. The green lines labeled 1 and 2 are the locations of topographic profiles shown in Figure 12. The green patterns labeled RD are rectilinear depressions. Unit Skr (black curvilinear pattern) is rusty-weathering hornfels or granofels and phyllite of the Silurian Kittery Formation (Hussey et al. 2016).
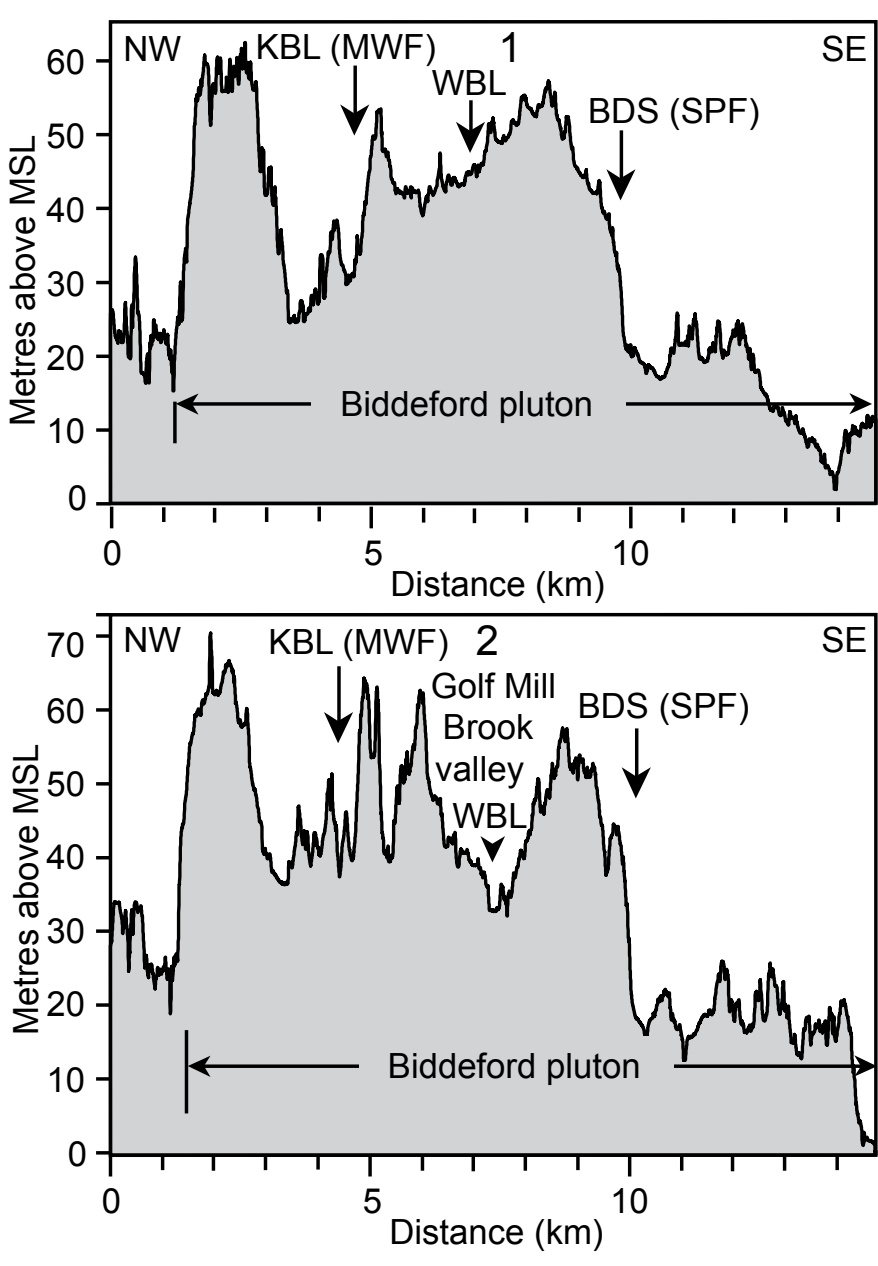

Figure 12. Topographic profiles showing the BDS and the linear depressions and valleys along KBL, WBL, and other LiDAR lineaments where they cross the Biddeford pluton. Profile locations are shown on Figure 11b.

of landslides are typically curved and formed mostly in the fine-grained sediments of the Presumpscot Formation along river valleys and the coast (Dickson and Johnston 2015) whereas the scarps along the lineaments are linear and formed in drumlin deposits (e.g., Fig. 9), which are less susceptible to slope failure. Furthermore, some scarps are formed in bedrock, such as the Biddeford and Lords Brook scarps (Figs. 5 and 11). The lineaments are also not related to lithologic boundaries or foliation because most of them cross plutons (Figs. 11 and 17), which lack foliation. Moreover, although the lineaments in some areas may parallel foliation in the Merrimack and Central Maine terranes, many of the longer lineaments, such as the BMD, lineaments SL1 and SL2, and the Kennebunk, Wells, Payneton, and Bloody Brook lineaments, cross both terranes and the adjacent plutons (Figs. 3b, 17b, and 23). We also considered the possibility that the curved BMD could be associated with a partial ring fracture that formed during emplacement of the Agamenticus pluton. However, the BMD continues southward across the Kittery Formation (Figs. 17b and 20). Lastly, a few of the lineaments coincide with mapped faults, such as the Beech Road lineament along part of the Nannie Island fault, the zone of LiDAR lineaments southwest of the Lyman pluton that coincides with the Calef fault, and the Peverly Brook lineament that coincides with part of the Dover Point fault (Fig. 7b). Another observation that supports a fault origin is the near coincidence of the Wells lineament with the Wells magnetic lineament (Fig. 17b). It is likely, therefore, that the linear depressions formed by erosion along brittle faults and that the linear scarps formed by vertical fault displacements.

\section{Southwest continuation of the NFS}

The continuity of the NRF, MRF, and SPF southwest of the Saco River strongly suggests that the NE-SW-trending lineaments in the study area are associated with the southwest continuation of the NFS along a broad 30- to $50-\mathrm{km}$-wide zone. For example, the conspicuous alignment of the NRF west of Casco Bay with SL1, Lords Brook scarp, and the zone of lineaments southwest of the Lyman pluton (Figs. 2 and 7a) suggests that it continues to the southwest as a zone of discontinuous, low-displacement brittle faults.

The alignment of the SPF with the Biddeford scarp, BMD, THZ, the Wells, Folly Pond, Payneton, and Beech Road lineaments, and the northeastern part of the Nannie Island fault (Figs. 2, 3, and 7b) suggests that it too continues 60 

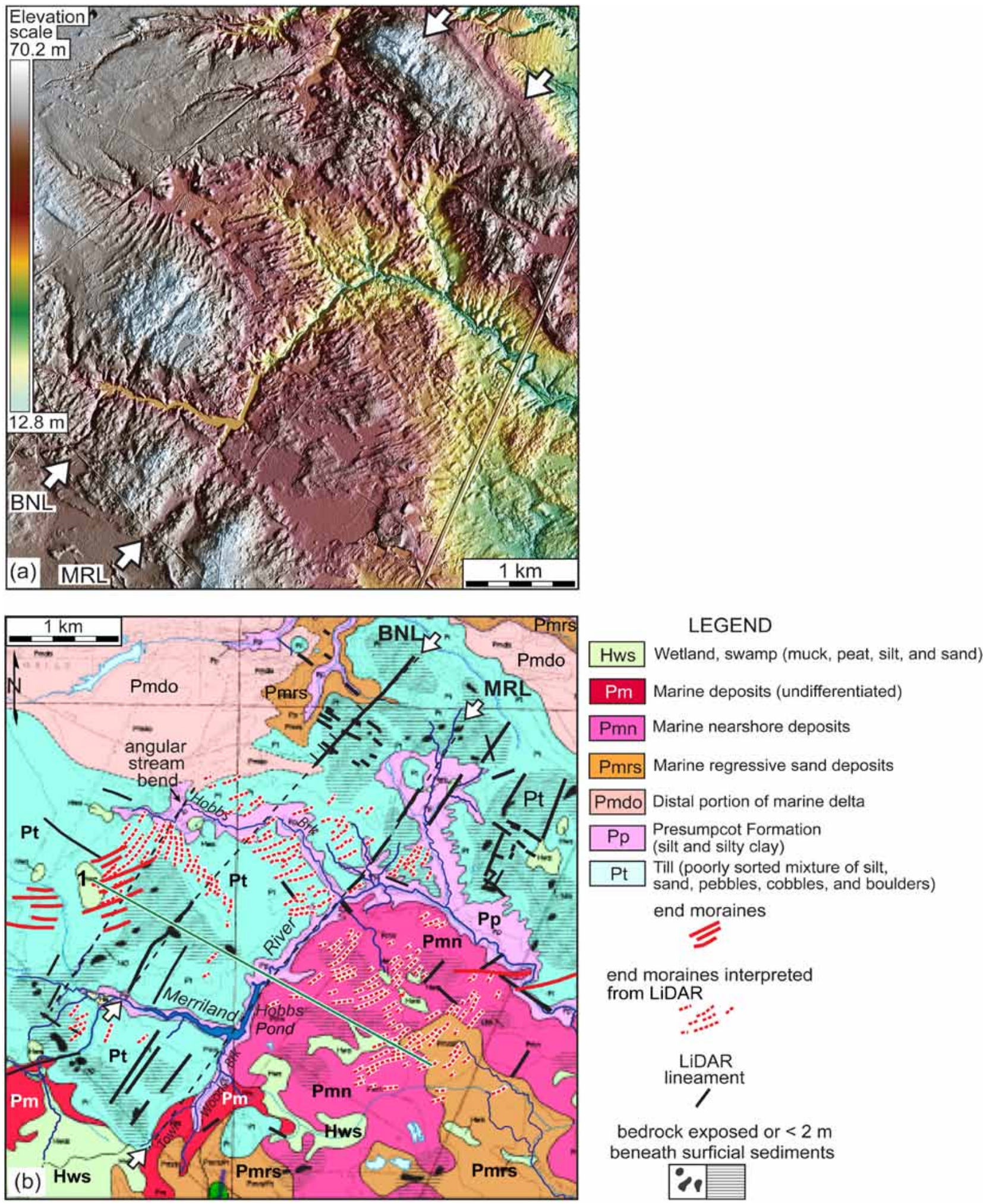

Figure 13. (a) LiDAR image showing the Burnt Road (BNL) and Merriland River (MRL) lineaments along the southwest projection of the MWF where they cross the Webhannet pluton. Image location is shown in Figure 2. (b) Interpretation of diagram (a) overlain onto the surficial geology of Neil (1999) and Smith (1999b, 1999c, and 1999e) to show that the topographically higher area west of the MRL is underlain by till deposits. The black lines are interpreted LiDAR lineaments. The green line is the location of the topographic profile in Figure 14. 


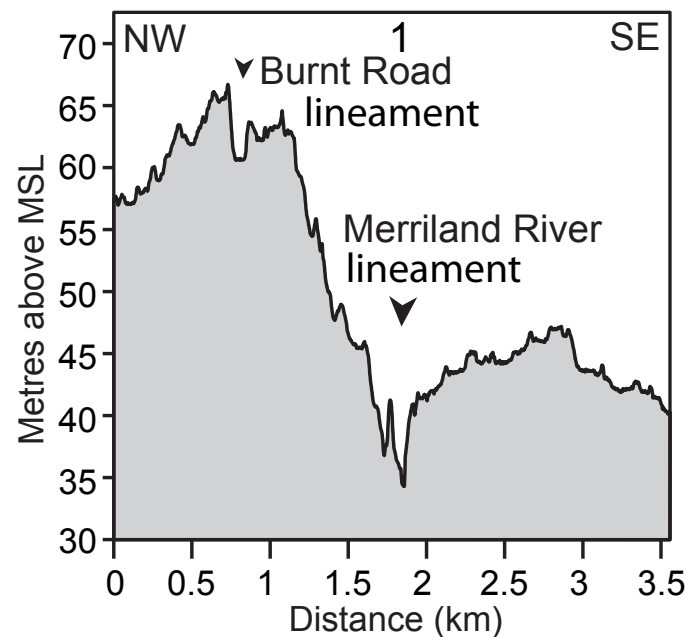

Figure 14. Topographic profile showing the linear depressions along the BNL and MRL. Profile location is shown on Figure 13b.

$\mathrm{km}$ to the southwest to at least the Great Bay estuary. We hypothesize that the SPF continues another $25 \mathrm{~km}$ southwest of the Great Bay estuary along the Bloody Brook lineament, but with a $1.5-\mathrm{km}$-wide, right-step offset at Great Bay (Fig. 29). Because the oblique orientation of the SPF relative to $S_{\text {Hmax }}$ favors dextral displacements, the $~ 35$-m-deep depression at the Great Bay offset likely represents a gentle pull-apart basin (Fig. 29). Although no large $(>1 \mathrm{~km})$ dextral displacements have been documented along the proposed SPF to the southwest, studies of restraining bends along strike-slip faults (Mitra and Paul 2011) suggest that only a few tens of metres of dextral displacement along the SPF would be needed to produce the depression at Great Bay. Such a small amount of dextral displacement would be difficult to identify in New England because of the thick glacial and glaciomarine sediments.

The MWF appears to continue another $30 \mathrm{~km}$ to the southwest because of its alignment with the Kennebunk and Merriland River lineaments where they cross the Biddeford and Webhannet plutons (Fig. 2). Offshore, Marple and Hurd (2019) postulated that the 45-km-long Poseidon lineament and scarp (Fig. 2) could also be part of the NFS to the southwest.

These longer lineaments and the numerous shorter, NESW-trending lineaments that cross most of the study area (e.g., Fig. 2) are likely surface expressions of post-Triassic, low-displacement faults associated with a major regional NE-SW-oriented zone of strain along the southwest continuation of the NFS (Fig. 29). The weakest aspect of this hypothesis is the lack of continuity of the lineaments between the more erosionally resistant plutons. This lack of continuity can be explained, however, by the presence of thicker glacial and glaciomarine sediments in the topographically lower areas between the plutons (Fig. 2) where faults are likely concealed.

\section{Discontinuous nature of the NRF and the origin of Saco ridge and Lords Brook scarp}

Unlike previous investigations that show the NRF as a smooth linear fault (e.g., Osberg et al. 1985), the LiDAR images reveal that the NRF is discontinuous with bends and offsets, such as the 2-km-wide right-step offset between the Stroudwater River lineament and the NE-SW-trending segment of the Presumpscot River (Fig. 29). Saco ridge to the southwest likely represents an area of uplift between the two interpreted faults represented by lineaments SL1 and SL2 (Fig. 29), both of which partly coincide with previously mapped faults near both sides of the ridge (Berry and Hussey 1998) (Fig. 3b).

The oblique orientation of the Lords Brook scarp relative to the NRF (Fig. 2) suggests that it is likely a fault scarp associated with up-to-the-west, reverse-style displacements (Fig. 29). The interpreted fault scarp is likely Permian or younger since it crosscuts the Permian Lyman pluton whereas Saco ridge is Pennsylvanian or younger in age since it crosscuts the Pennsylvanian Saco pluton (Gaudette et al. 1982). These geomorphic features are, therefore, likely surface expressions of a discontinuous NRF that continues to the southwest along Saco ridge, Lords Brook scarp, and the zone of NE-SW-trending lineaments to the southwest, rather than along the NRF of Hussey et al. (2016) (Fig. 29).

\section{Agamenticus pop-up and other interpreted structures across the Agamenticus pluton}

The diverse trends of long $(>2 \mathrm{~km})$ linear depressions across the Agamenticus pluton (Fig. 17) strongly suggest that this area is structurally complex. The main cause of the structural complexity appears to be from the intersection of the proposed SPF with this circular pluton. For example, the interpreted SPF appears to have crossed the pluton along the curved BMD (Fig. 17). This hypothesis is supported by the proximity of the BMD to Mount Agamenticus, Second Hill, and Third Hill, which is anomalous because they are all underlain mostly by alkali granite (unit Trg, Fig. 17b), indicating that these terrain features did not form simply by differential erosion caused by changes in bedrock composition. Nor is the BMD associated with an igneous ring fracture since it continues southward across the Kittery Formation (Figs. 17 and 18, profiles 5, 7, and 8). We therefore postulate that the post-Triassic reactivation of the SPF's ductile roots at depth fractured around the central core of the pluton along the BMD. This hypothesis is supported by previous studies of seismicity near plutons (e.g., Stevenson et al. 2006), which suggest that the edges of plutons are areas of weakness. More recently, the SPF 

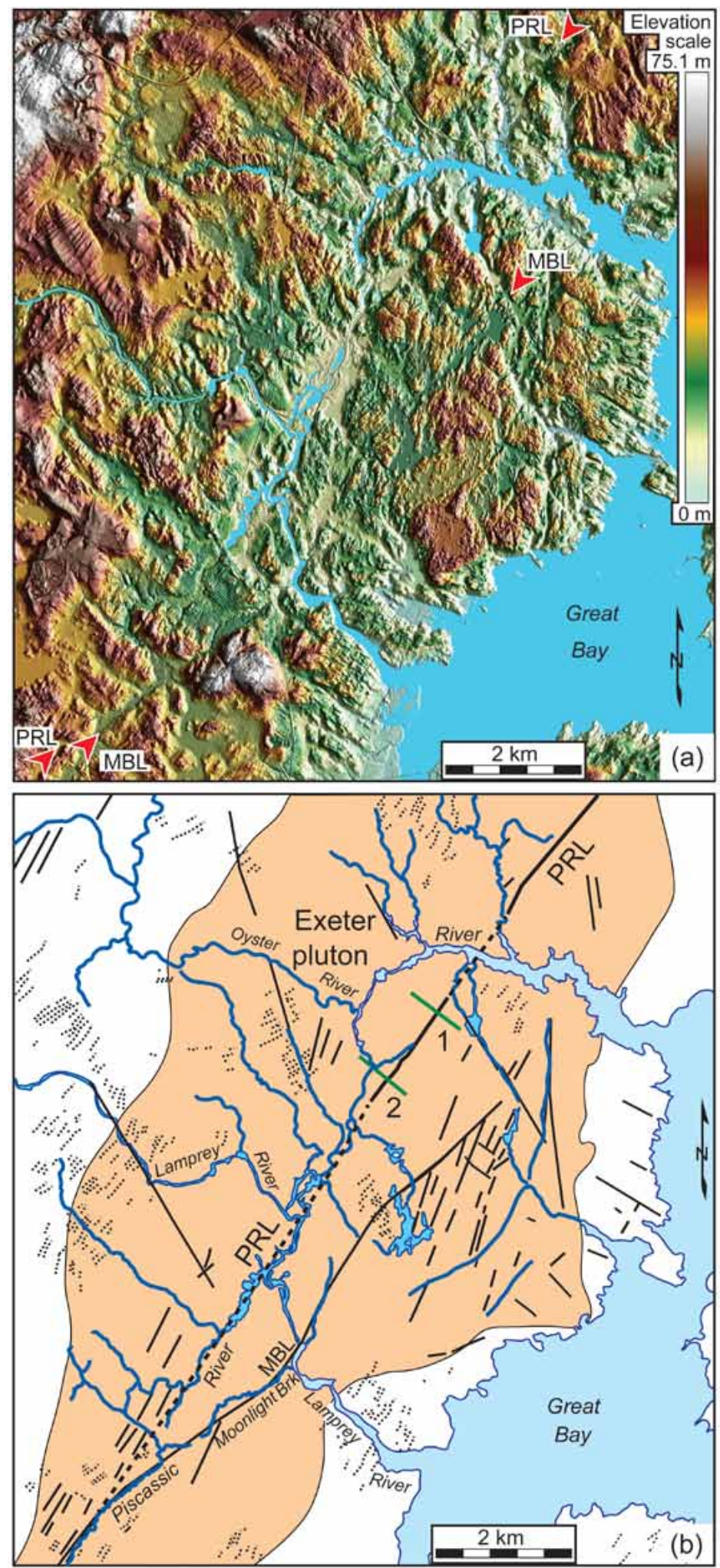

Figure 15. (a) LiDAR image showing the Piscassic River (PRL) and Moonlight Brook (MBL) lineaments across the Exeter pluton. Image location is shown in Figure $7 \mathrm{~b}$. (b) Interpretation of diagram (a) showing the locations of the PBL, MBL, and other shorter lineaments (black lines) along linear valleys and straight river segments overlain with the recessional moraines (thin dashed lines) interpreted from the LiDAR image. The green lines are the locations of topographic profiles shown in Figure 16. 


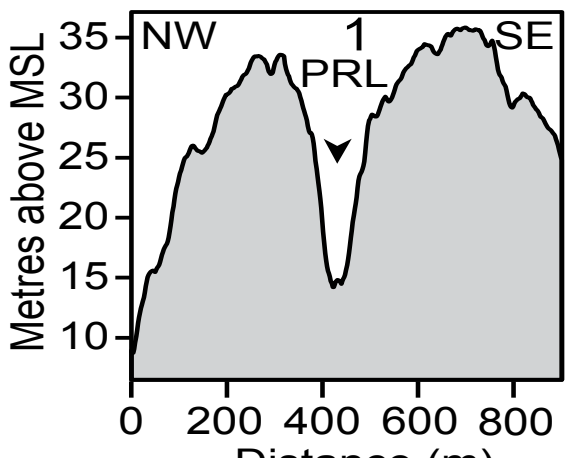

Distance $(\mathrm{m})$

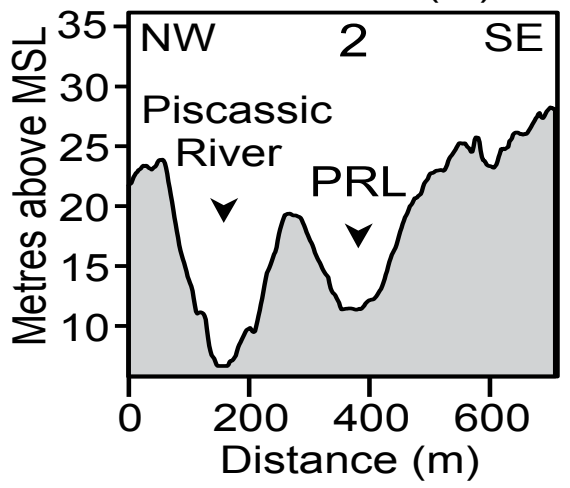

Figure 16. Topographic profiles showing the association of the PRL with linear valleys and drainage patterns. Profile locations are shown on Figure 15b.

appears to have fractured along a more direct, but segmented path across the pluton along the THZ and the Folly Pond and Payneton lineaments (Fig. 29). The parallelism of the THZ with the Folly Pond lineament (Fig. 17b) suggests that the SPF is a segmented, en échelon fault zone across the Agamenticus pluton (Fig. 29). Stresses associated with dextral displacements along the intersecting Folly Pond and Payneton lineaments have likely produced a cross-fault along the Chases Pond lineament along which up-to-thenortheast reverse or thrust displacements have occurred (Figs. 18, profile 9, and 29). This hypothesis is supported by the dramatic increase in elevation northeast of the Chases Pond lineament (Fig. 18, profile 9), which suggests that the area bounded by the BMD, THZ, and the Chases Pond and Folly Pond lineaments may have been uplifted by upto-the-NE displacements along part of the Chases Pond lineament, thus resulting in Mount Agamenticus, Second Hill, and Third Hill, herein referred to as the Agamenticus pop-up (Fig. 29). The intersection of the Groundnut Hill lineament with the gentle southward bend in the interpreted SPF near the northern edge of the Agamenticus pluton and the higher terrain along the west side of this lineament (Fig. 18, profile 1) suggests that the Groundnut Hill lineament is associated with a west-dipping reverse or thrust fault formed by stresses caused by dextral motion along this bend in the SPF (Fig. 29). The small Cenozoic fault slip rates in the eastern United States (Prowell and Obermeier 1991) and the oblique orientation of SHmax relative to the SPF since Early Cretaceous time (e.g., Faure et al. 1996) suggest that at least some dextral displacement has occurred along the SPF to form these areas of uplift (Fig. 29). Although there is no evidence for large-scale $(>1 \mathrm{~km})$ dextral displacements along the interpreted SPF, experimental studies of restraining bends along strike-slip faults by Mitra and Paul (2011) suggests that the amount of lateral displacement required to produce these areas of uplift would have been no more than 2 to 3 times the amount of vertical deformation that produced these uplifted areas. Thus, only a few hundred metres of dextral displacement on the nearby SPF would have been required to produce the Agamenticus pop-up. The interpreted right-step offset in the southern edge of the contact aureole (Kittery Formation) bounding the pluton along the Payneton scarp to the southwest (Fig. 20) may represent $300-500 \mathrm{~m}$ of dextral displacement along the interpreted SPF to the southwest, which would have been sufficient to produce the compressional pop-up.

\section{Possible cause of low-level seismicity along the NFS}

The low-level seismicity along the NFS (e.g., Ebel and Spotila 1999) is perplexing since the orientation of the NFS relative to $S_{H \max }$ favors right-lateral displacements. One possible explanation for this observation is that the NFS could be locked between large earthquakes that occur at long recurrence time intervals. Examples of locked, currently aseismic faults that have produced large historical earthquakes include the large segments of the San Andreas fault that ruptured in 1857 and 1906 (Wallace 1990). Similarly, Guccione et al. (2005) hypothesized that the Bootheel fault in the New Madrid region may be locked because of its structurally complex nature. The proposed NFS in southern Maine and southeastern New Hampshire is also characterized by structural complexities in several areas, including the discontinuous nature of the NRF, the segmented nature of the SPF where it crosses the Agamenticus pluton, the interpreted Great Bay pull-apart basin, and the Kingston restraining bend (Fig. 29).

\section{SPF as the principal displacement zone of the NFS southwest of Casco Bay}

At least three observations suggest that the SPF is the principal displacement zone of the NFS southwest of Casco Bay. First, the interpreted location of the SPF, unlike the NRF, is collinear with the main trend of the NFS to the northeast (Fig. 1). Secondly, it can be traced farther southwest than other lineaments in the central part of the study area (Fig. 2). Third, the density of lineaments is greatest along 


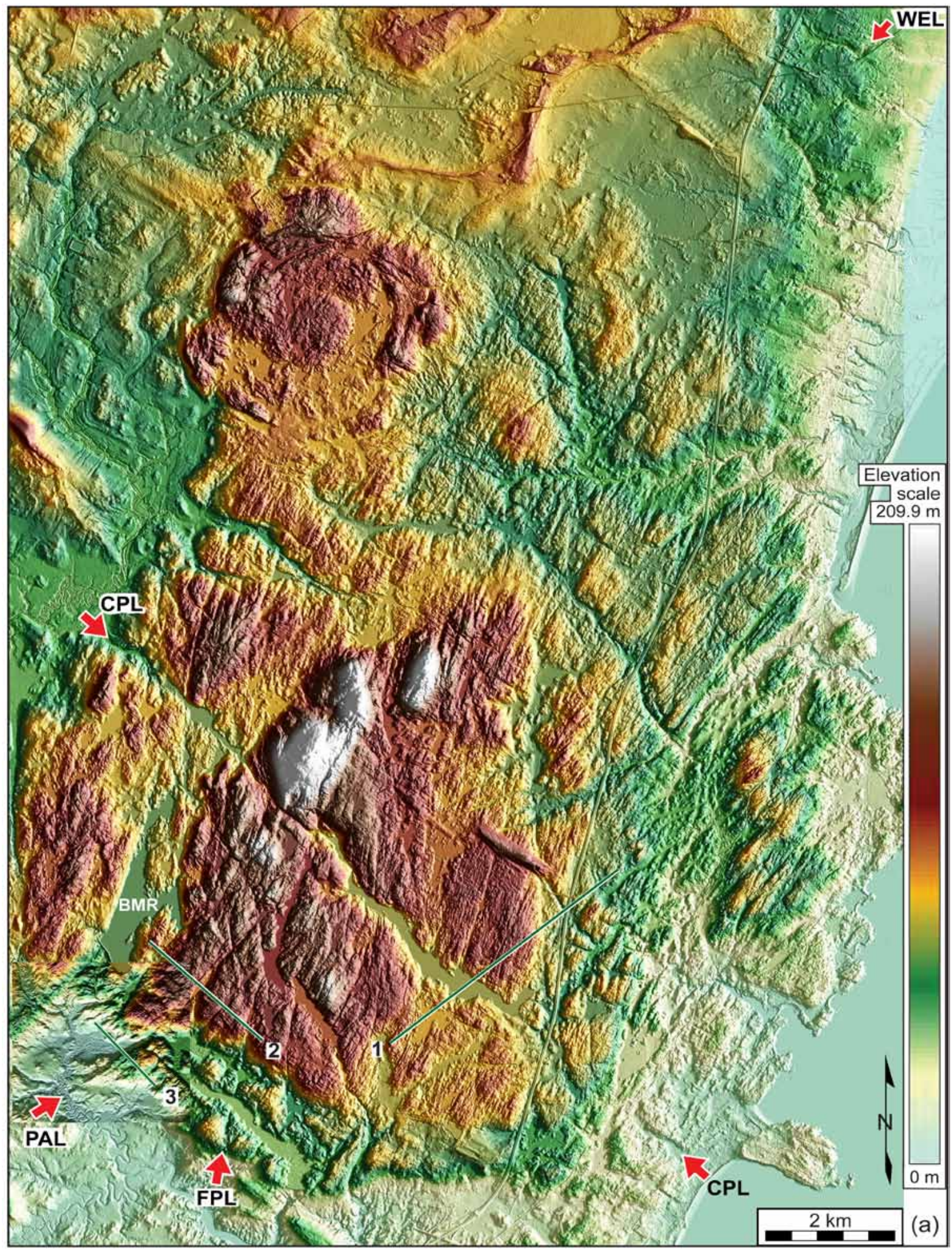

Figure 17. (a) Enlarged LiDAR image showing the Bell Marsh depression (BMD) and the Wells (WEL), Payneton (PAL), Chases Pond (CPL), Folly Pond (FPL) and numerous other shorter lineaments crossing the Agamenticus pluton and the area to the north along the southwest projection of the South Portland fault. The green lines are the locations of elevation profiles shown in Figure 18. Image location is shown on Figure 2. BMR is the Bell Marsh Reservoir. 


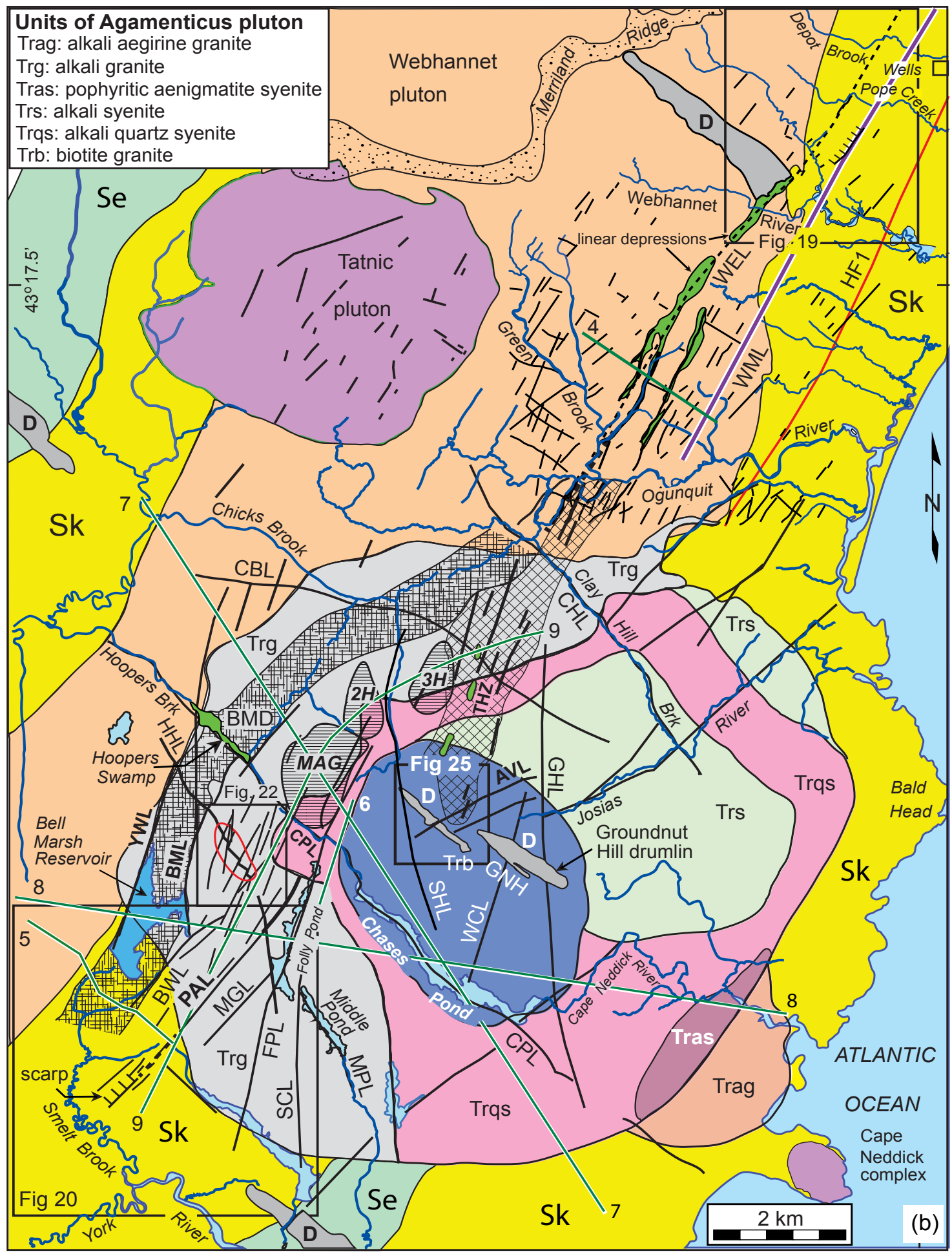

Figure 17. (b) Interpretive map of diagram (a) with the bedrock geology of Hussey et al. (2016) overlain. The light grey patterns (labeled D) are drumlins. MAG, $2 \mathrm{H}$, and $3 \mathrm{H}$ are the locations of Mount Agamenticus, Second Hill, and Third Hill. Cross-lined pattern is the BMD. Red closed contour circling part of the Horse Hills lineament (HHL) shows interpreted 30- to 50-m size right-lateral offsets of the HHL along NNE-SSW-trending lineaments. The green lines are the locations of elevation profiles shown in Figure 18. Purple line labeled WML is the Wells magnetic lineament. Se (light green) and Sk (yellow) are the Eliot and Kittery formations. The cross-hatch pattern east of Third Hill shows the location of the Third Hill zone of linear depressions (THZ). Abbreviations for faults and lineaments are listed in Tables A1 and A2 in the Appendix. 

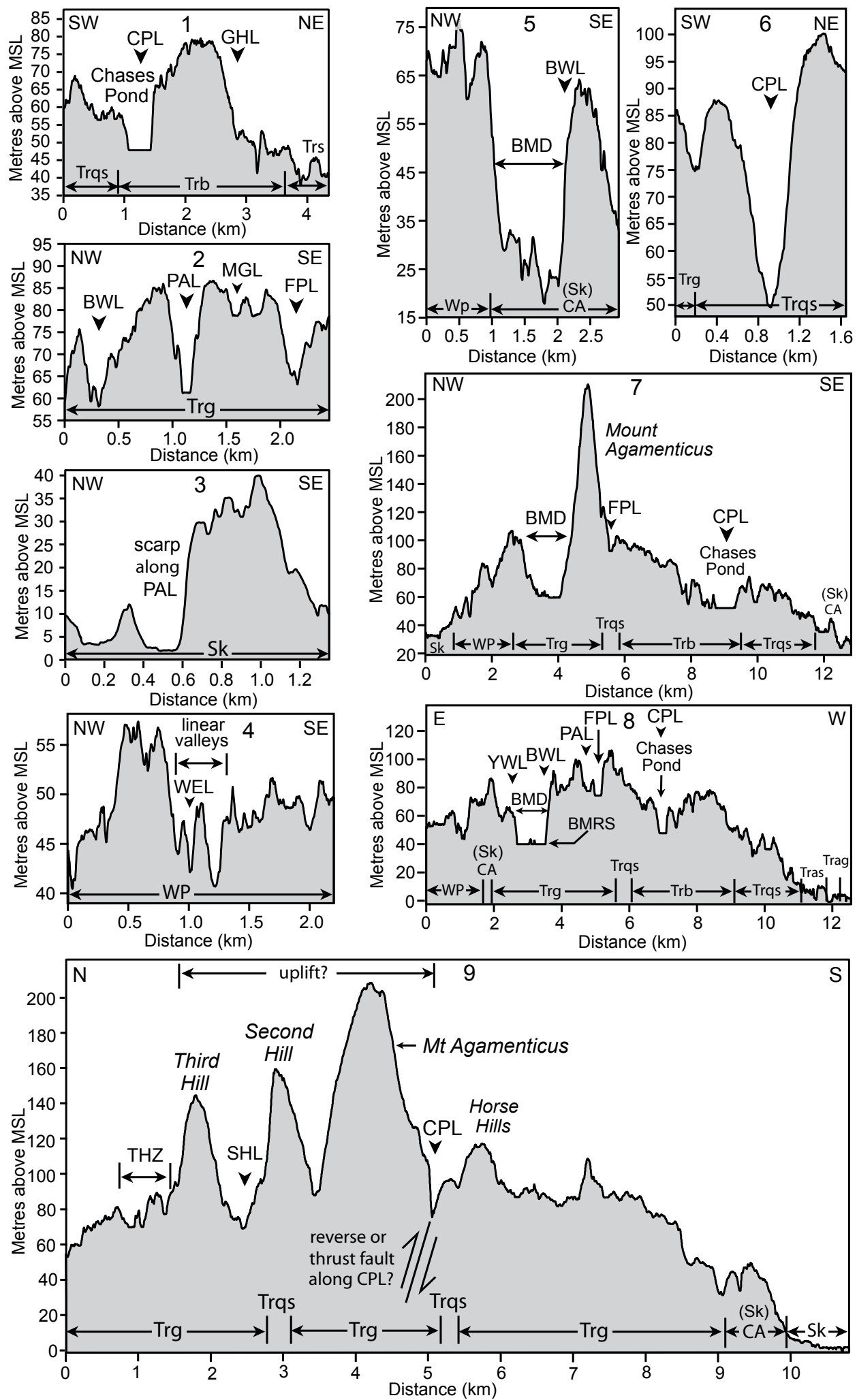

Figure 18. Topographic profiles showing linear valleys and scarps along the more prominent LiDAR lineaments with the geologic units overlain, as well as anomalously elevated terrain adjacent to the BMD, such as Mt Agamenticus. BMRS is the surface of the Bell Marsh Reservoir. CA is the contact aureole within the Kittery Formation (Sk). The inset in Figure 17b explains geologic units of the Agamenticus pluton. Profile locations are shown on Figures 17a and 17b. Lineament abbreviations are listed in Table A2 in the Appendix. 


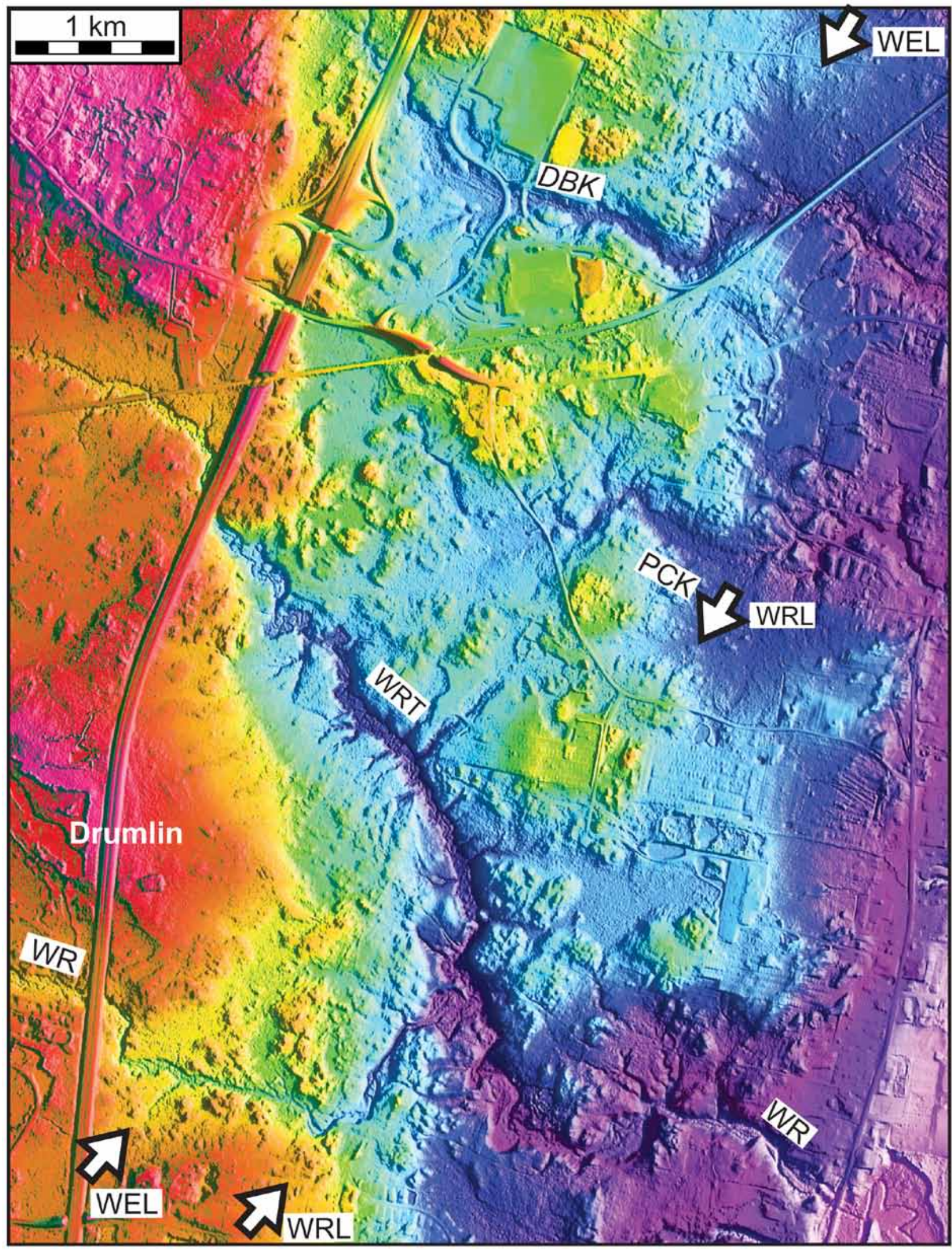

Figure 19. Enlarged, IHS-enhanced portion of Figure 17a (location shown in Fig. 17b) showing right-lateral bends in rivers along the Wells lineament (WEL). DBK, PCK, WR, and WRT are the Depot Brook, Pope Creek, Webhannet River, and tributary of the Webhannet River, respectively. WRL is the Webhannet River lineament. 


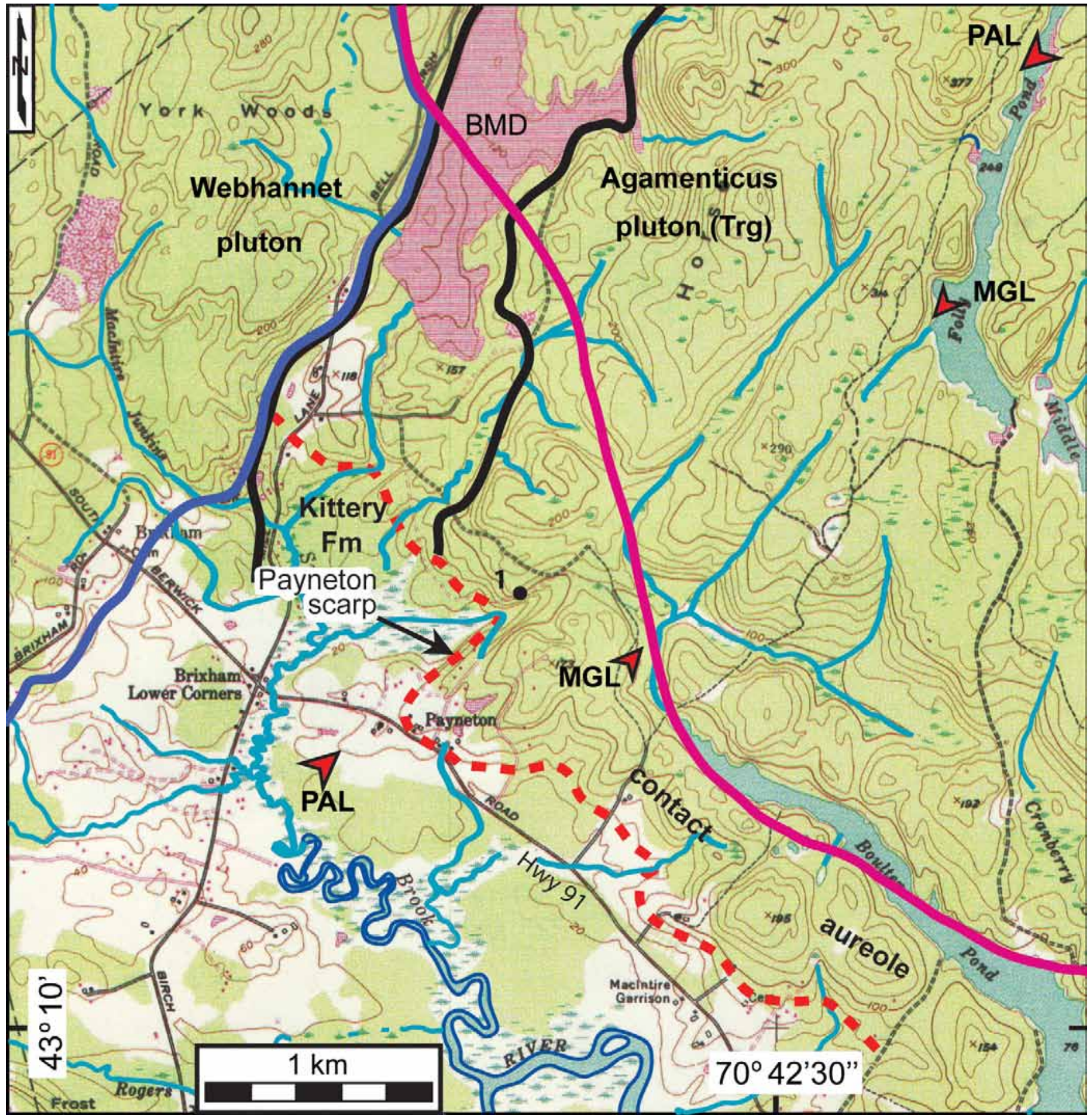

Figure 20. Portion of York Harbor 1:24 000-scale topographic map (location shown in Fig. 17b) showing the locations of the Payneton lineament and scarp where they cross the Kittery Formation and Agamenticus pluton. Contour interval = 20 feet. The thick blue contour is the southeast boundary of the Webhannet pluton and the red contour is the southwest boundary of the alkali granite unit Trg of the Agamenticus pluton. The BMD lies between the two black contours. The interpreted edge of the contact aureole within the Kittery Formation is shown as the elevated terrain between the red dashed line and the Agamenticus pluton (red contour). 


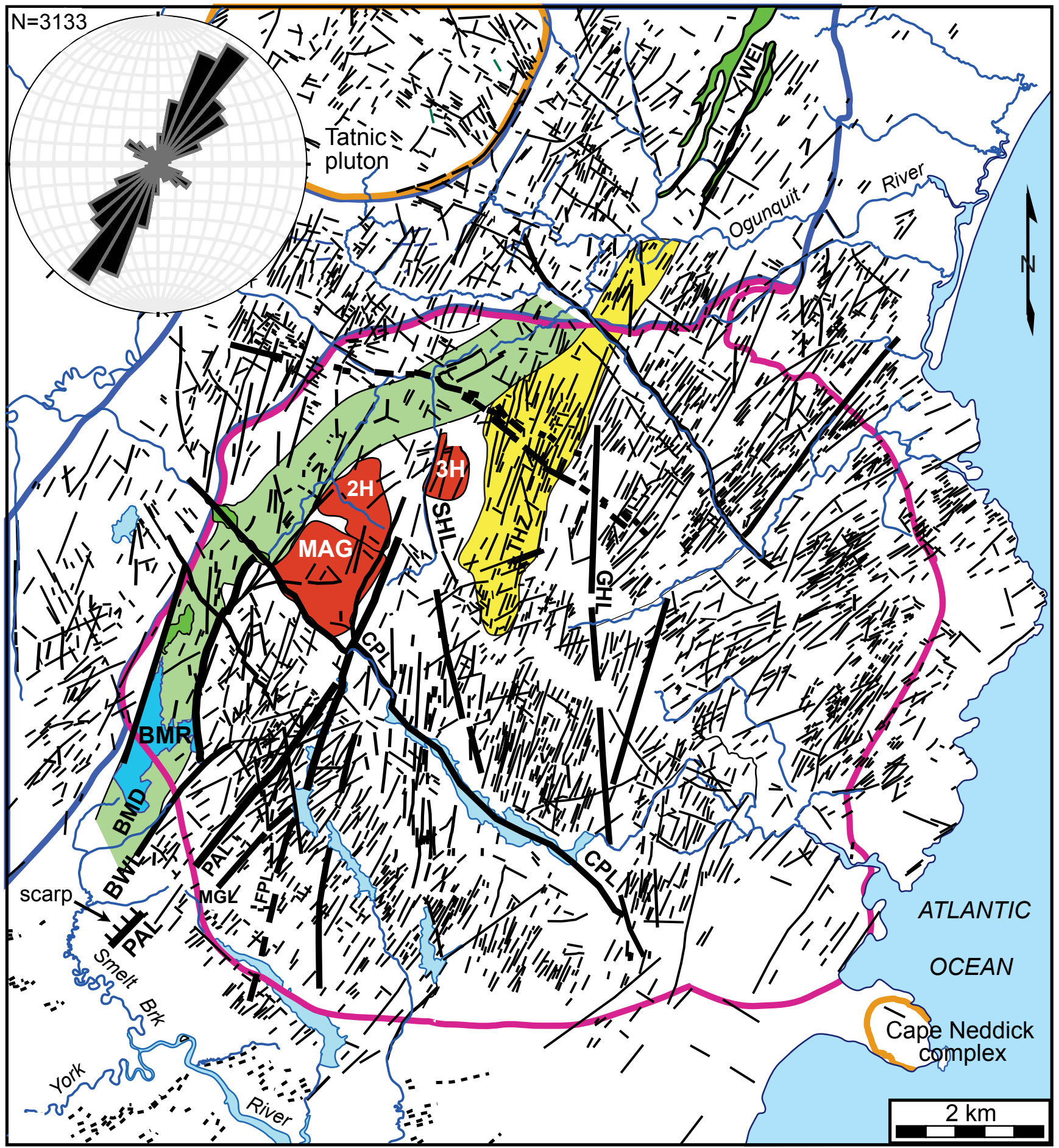

Figure 21. Lineament map of the Agamenticus pluton (red contour) interpreted from LiDAR images illuminated from different directions. The rose diagram shows the various orientations of LiDAR lineaments. The red patterns labeled MAG, $2 \mathrm{H}$, and $3 \mathrm{H}$ are Mount Agamenticus, Second Hill, and Third Hill. The green pattern is the BMD; BMR is the Bell Marsh Reservoir. The yellow pattern east of Third Hill shows the location of the THZ. The green patterns near the northern edge of the map are linear valleys along the Wells lineament (WEL). The Webhannet pluton lies within the blue contours and the Tatnic pluton and Cape Neddick complex (CNC) lie within the orange contours. The thin dashed lines near the southern edge of the map are the locations of recessional moraines. 

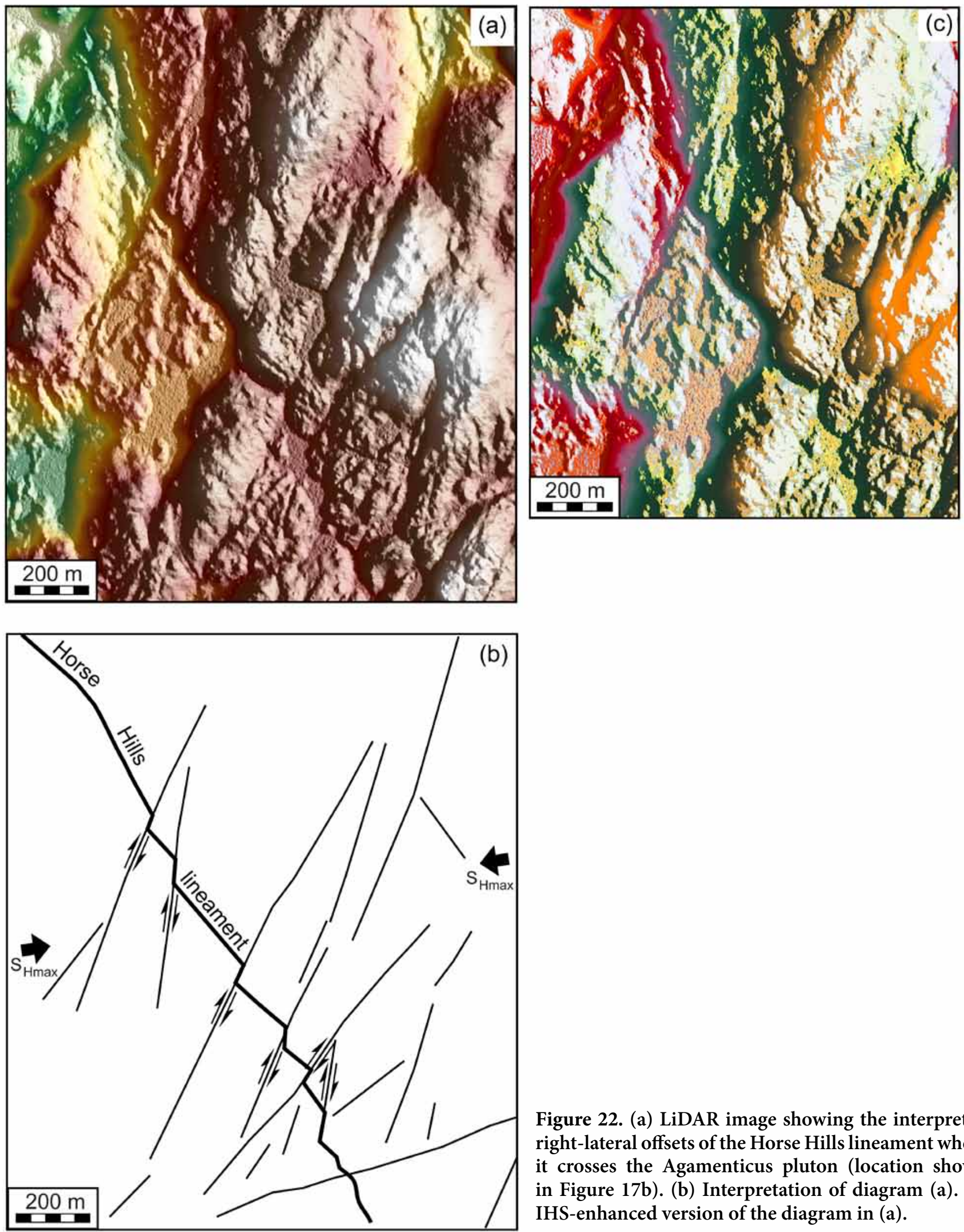

Figure 22. (a) LiDAR image showing the interpreted right-lateral offsets of the Horse Hills lineament where it crosses the Agamenticus pluton (location shown in Figure 17b). (b) Interpretation of diagram (a). (c) IHS-enhanced version of the diagram in (a). 

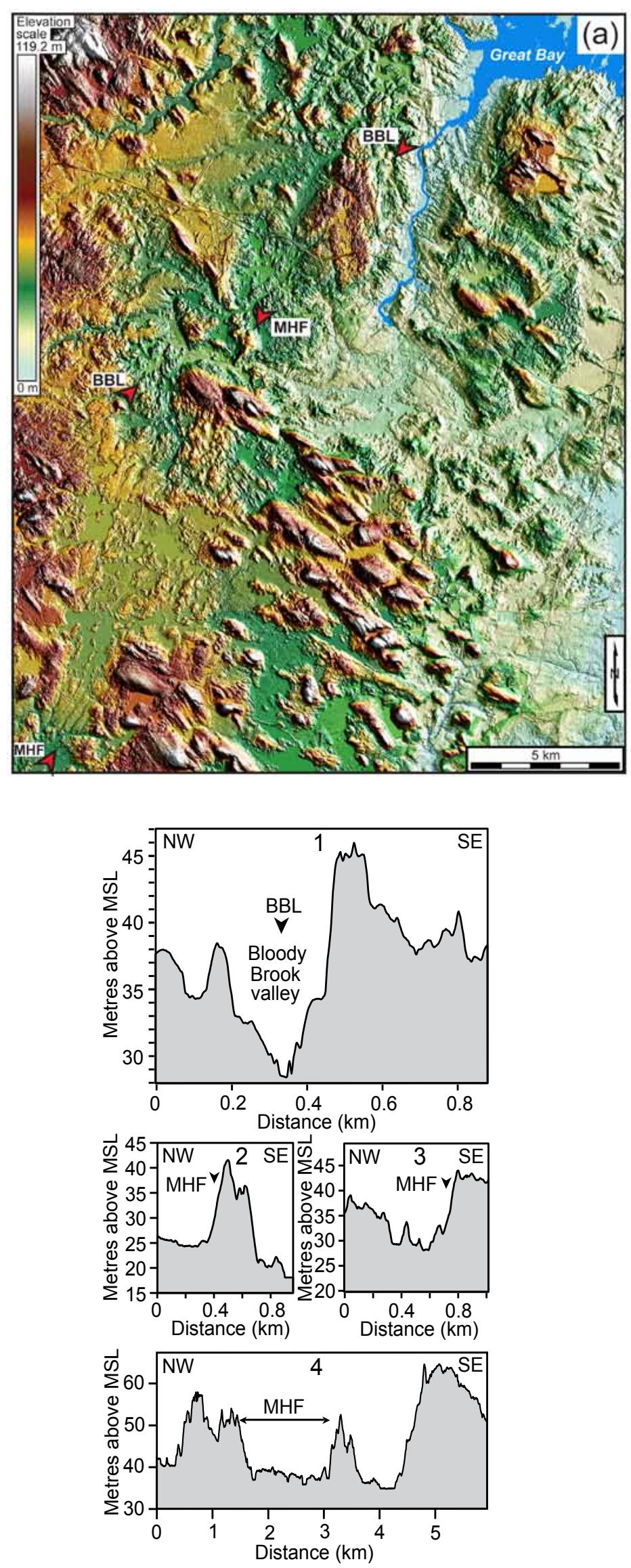

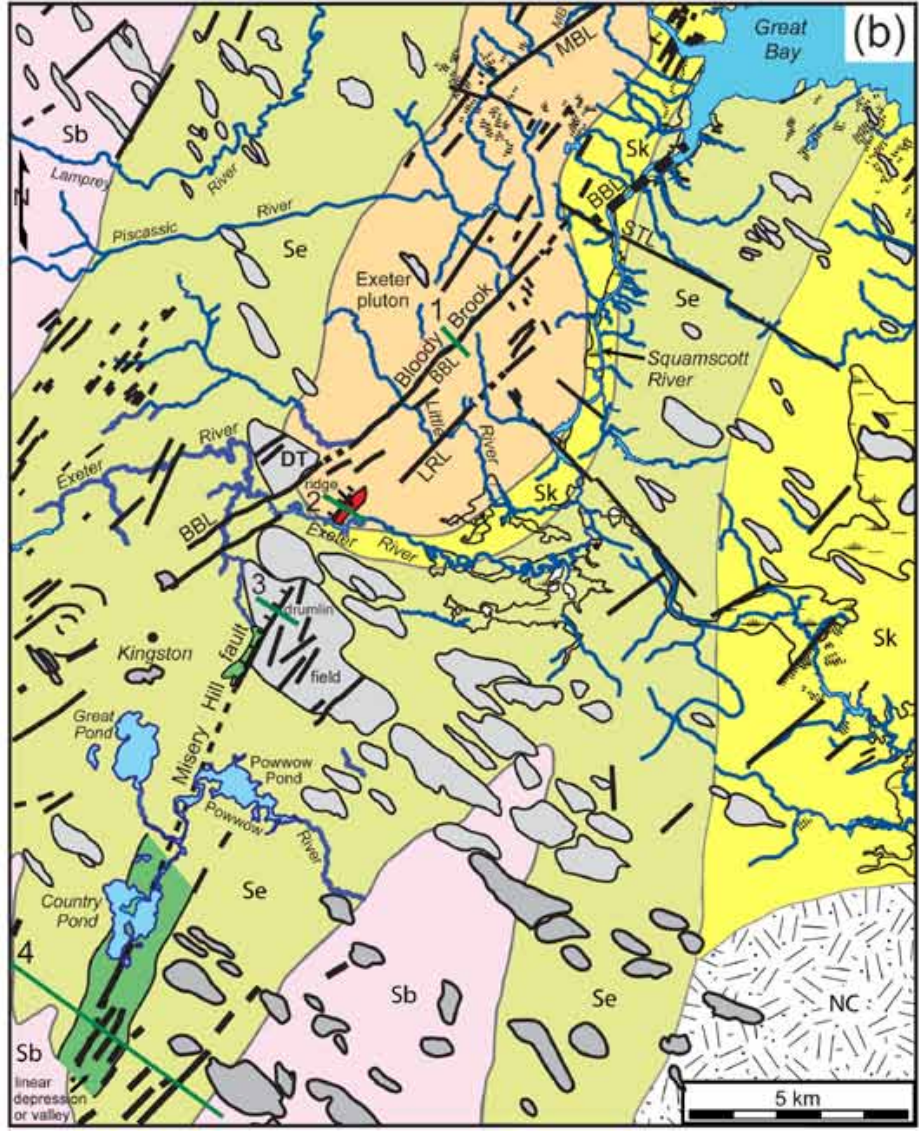

Figure 23. (above) (a) LiDAR image showing the intersection of the Bloody Brook lineament (BBL, between opposing arrows) and the Misery Hill fault (MHF). Image location is shown in Figure 2. (b) Interpretation of diagram (a) overlain with the bedrock geology of Lyons et al. (1997). Patterns labeled Sb, Se, and Sk are the Berwick, Eliot, and Kittery formations. NC is the Newburyport igneous complex. The grey patterns are interpreted drumlins and the thin dashed lines are interpreted recessional moraines. Dark green pattern in the southwest corner is a linear depression along the MHF. DT is an interpreted drumlin that ends abruptly along the BBL. MB is Moonlight Brook. Abbreviations for faults and lineaments are shown in Tables A1 and A2 in the Appendix.

Figure 24. (left) Topographic profiles constructed across the BBL (profile 1) and MHF (profiles 2-4). Profile locations are shown in Figure 23.

the trend of the SPF, such as across the Agamenticus and Biddeford plutons (Figs. 11 and 17). Finally, the geomorphic expression of the SPF southwest of the Saco River, including the Biddeford scarp, Payneton and Folly Pond lineaments, THZ, and the Agamenticus pop-up (Figs. 11 and 17), is more conspicuous than along other lineaments in the study area. 

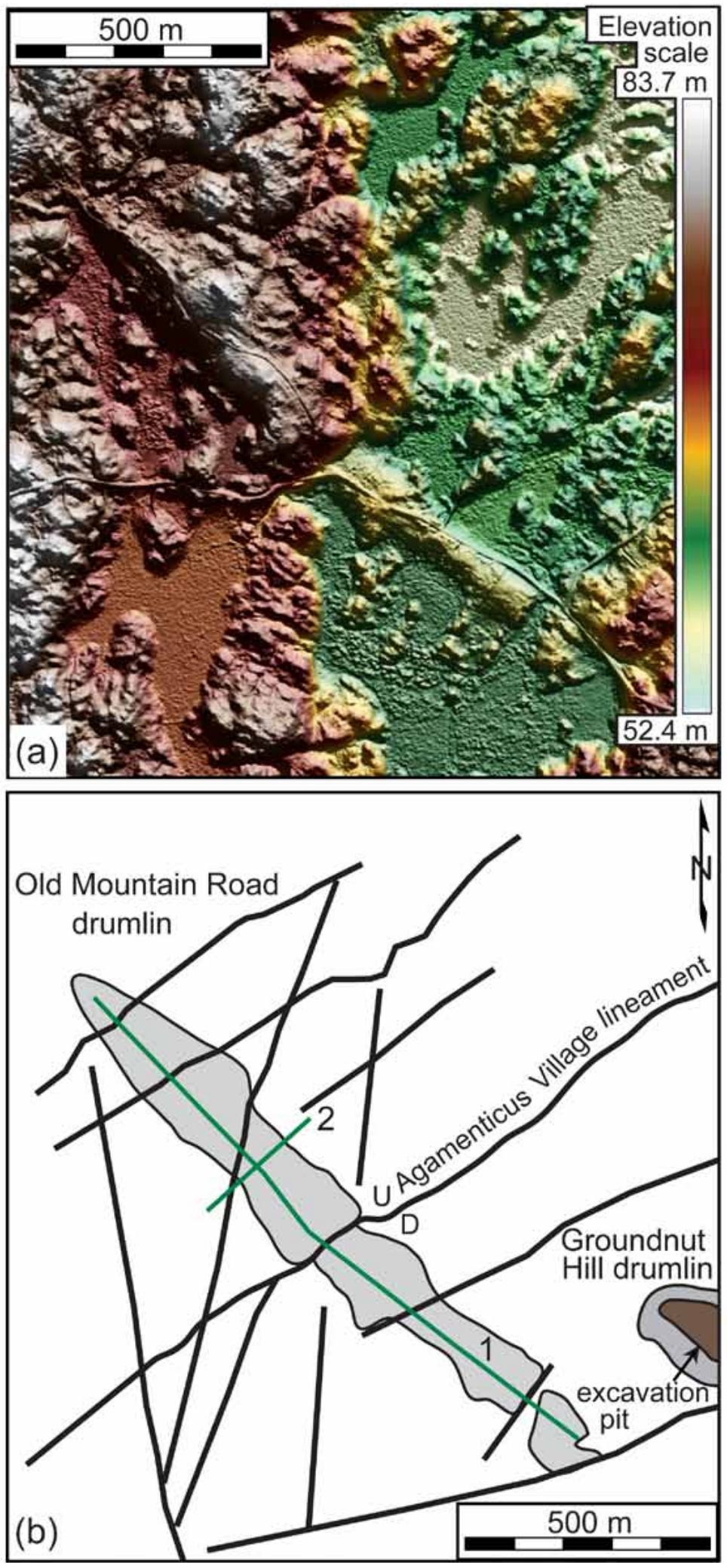

Figure 25. (a) LiDAR image (illumination azimuth $=020^{\circ}$ ) of the Old Mountain Road drumlin in southern Maine. Image location is shown on Figure 17b. (b) Interpretation of diagram (a) showing the location of the Agamenticus Village lineament (AVL) that coincides with the down-to-the-SE scarp that appears to vertically offset the Old Mountain Road drumlin. The green lines are the locations of topographic profiles shown in Figure 26. 

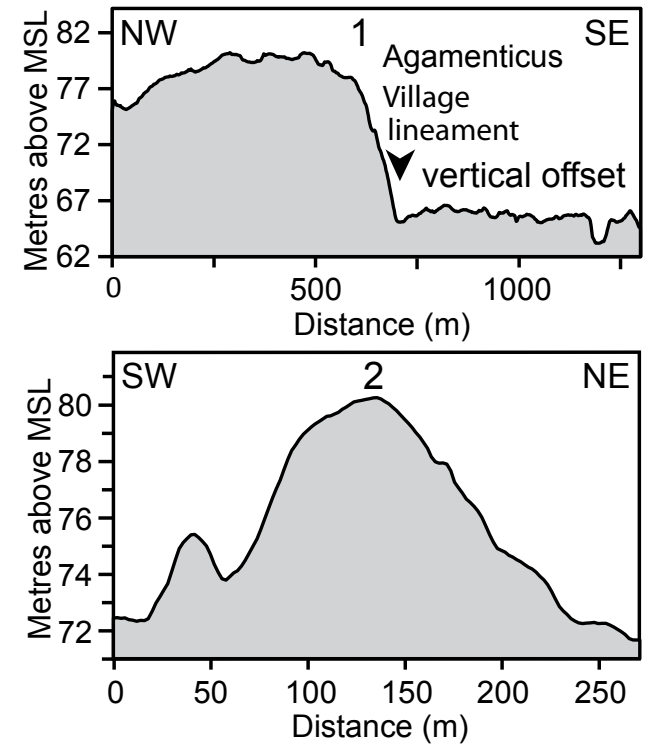

Figure 26. Topographic profiles showing the apparent vertical offset of the Old Mountain Road drumlin (profile 1) and its cross-sectional shape (profile 2) northwest of the scarp. Profile locations are shown on Figure 25b.

\section{Evidence for a major, NW-SE-trending structure near Biddeford, Maine}

Marple and Hurd (2019, figs. 4 and 5) revealed numerous NW-SE-trending features near Biddeford, Maine, that may represent a $\sim 30-\mathrm{km}$-long, NW-SE-trending structure that crosses the trend of the NFS. These features include the NW-SE-trending strikes of bedding and foliation northeast of the Biddeford pluton, the Biddeford Pool scarp and depression, the Biddeford gravity lineament, and the NWSE-oriented Biddeford pluton and Audrinas ring (Fig. 1). Additional evidence for this cross-structure includes the abrupt termination of the NE-SW-trending magnetic lineaments along NW-SE-trending magnetic lineaments northeast of the Saco River (Fig. 27), the NW-SE-oriented dextral-oblique reverse fault at Biddeford Pool (Fig. 28), and the NW-SE-trending LiDAR lineaments shown by the rose diagram of the Biddeford pluton (Fig. 11b). Marple and Hurd (2019) postulated that this structure formed by dextral deformation along the northeastern edge of a Devonian indenter that they named the Biddeford indenter (Fig. 30). They hypothesized that the indenter thrust the Merrimack terrane southwest of Casco Bay over the ductile roots of the NFS to the southwest during Devonian time. Later reactivation of the NFS at depth fractured through the overlying Merrimack terrane, thus producing the numerous NE-SW-trending LiDAR and sonar lineaments southwest of the Saco River and Biddeford Pool depression (Fig. 2). Such overthrusting of the NFS and later reactivation of its ductile roots could explain the dramatic change from large lateral displacements along the NFS northeast of Casco Bay (e.g., Ludman et al. 1999) to small $(<1 \mathrm{~km})$ lateral displacements to the southwest. Because of its NW-SE-orientation, the Biddeford pluton likely intruded upward along one of the NW-SE-trending fractures near the edge of the indenter.

Although the location of the northwestern edge of this overthrust block is uncertain, it may lie along the NWdipping Nonesuch River/Calef fault and the east-westtrending fault of Hussey et al. (2016) between the Biddeford and Saco plutons (labeled HF2 on Fig. 1) since the NW-SEtrending strikes of foliation and bedding of the Merrimack terrane do not continue northwest of the Biddeford pluton (fig. 5c of Marple and Hurd 2019). This location, combined with the greater thicknesses of glaciomarine sediments near the coast, could explain why the LiDAR lineaments along the southwest projection of the NRF are more continuous than those to the east where the overthrusting occurred. Overthrusting of the Norumbega's ductile roots is analogous to the basement fault associated with the New York-Alabama lineament that was overthrust by the Alleghanian thrust sheet (e.g., Steltenpohl et al. 2010).

A potential weakness of this hypothesis is the presence of NW-SE strikes in foliation of the Kittery Formation near the southwestern side of the Biddeford pluton. Swanson (2019) suggested that the NW-SE-trending foliation north and south of the Biddeford pluton is associated with regional Norumbega shearing southwest of Casco Bay. However, his hypothesis is based mainly on the southwest continuation of the NFS along the NRF since there are no other known Paleozoic continuations of the NFS southwest of the Saco River. Moreover, the concentration of NW-SE-trending features near Biddeford Pool (Fig. 1) suggests that there is a major cross-structure in this area.

\section{Peverly Brook and Little Bay lineaments}

The cross-cutting, NNE-SSW orientation of the Peverly Brook and Little Bay lineaments relative to the NE-SW trend of most lineaments in the study area (Fig. 29) is anomalous. The scarp along the Peverly Brook lineament near Newington, New Hampshire (Fig. 7c), is likely an eroded Pleistocene fault scarp because it crosses the trends of end moraines in the area (Marple et al. 2015). North of Great Bay, these lineaments coincide with parts of the Dover Point fault (Fig. 7b). Because these two lineaments cross the proposed right-step offset along the interpreted SPF at Great Bay, we hypothesize that they could be surface expressions of cross-faults associated with this offset (Fig. 29). 

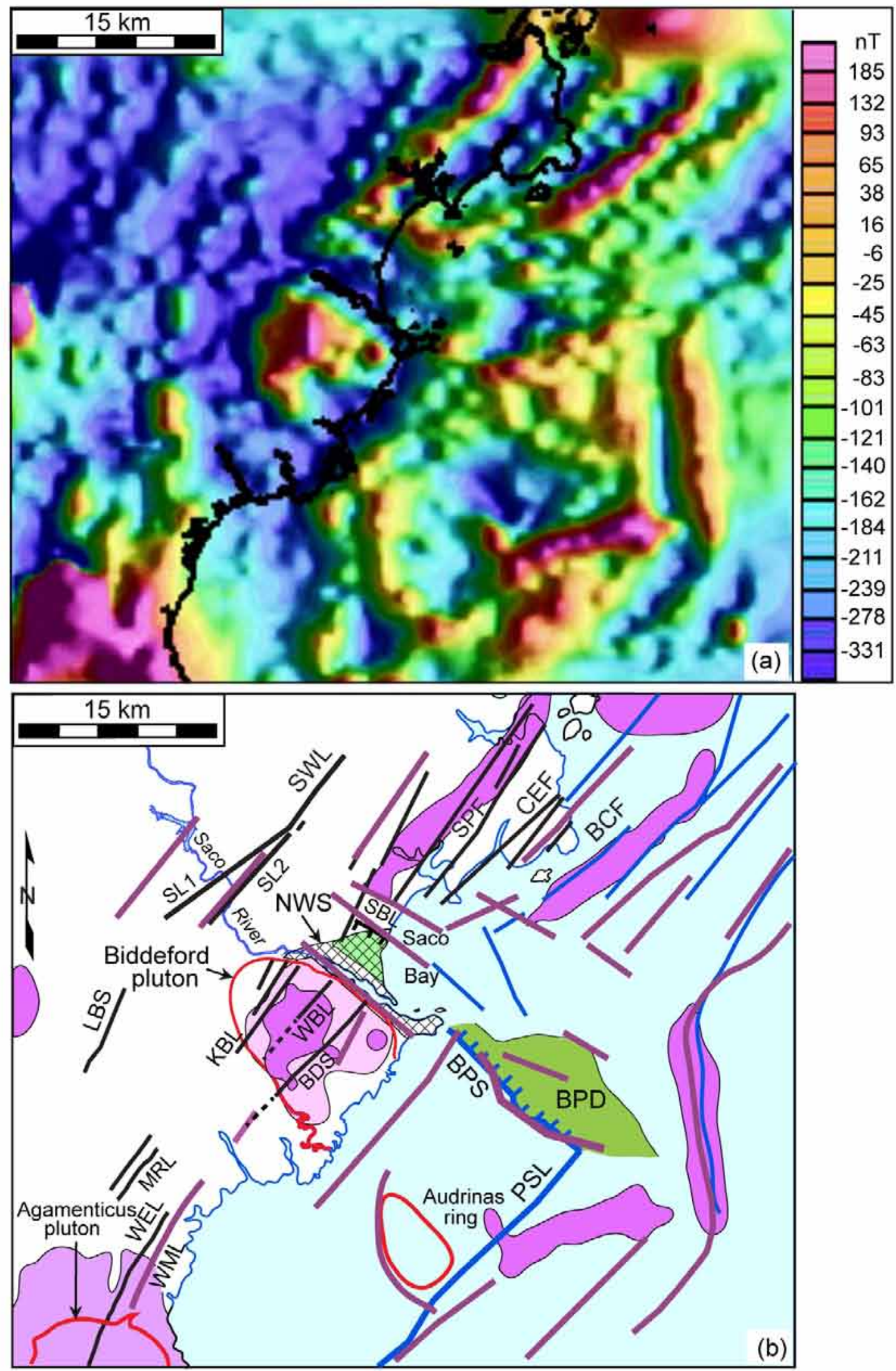
Figure 27. (previous) (a) Portion of aeromagnetic anomaly map of Daniels and Snyder (2004) in the area of Biddeford, Maine (location shown in Figure 2), showing the abrupt termination of NE-SW-trending magnetic lineaments northeast of the Biddeford pluton along short NW-SE-trending magnetic lineaments. Scale is in nanoteslas (nT). (b) Interpretation of diagram (a). Black lines are LiDAR lineaments. Blue lines are sonar lineaments interpreted from figure 5 of Marple and Hurd (2019). Purple lines are linear magnetic anomalies and purple patterns are positive aeromagnetic anomalies interpreted from diagram (a). Abbreviations for lineaments and scarps are listed in Table A2 in the Appendix. The crosshatch pattern northeast of the Biddeford pluton is the area of NW-SE-trending strikes of bedding and foliation of the Merrimack terrane and the green patterns are topographically low areas.

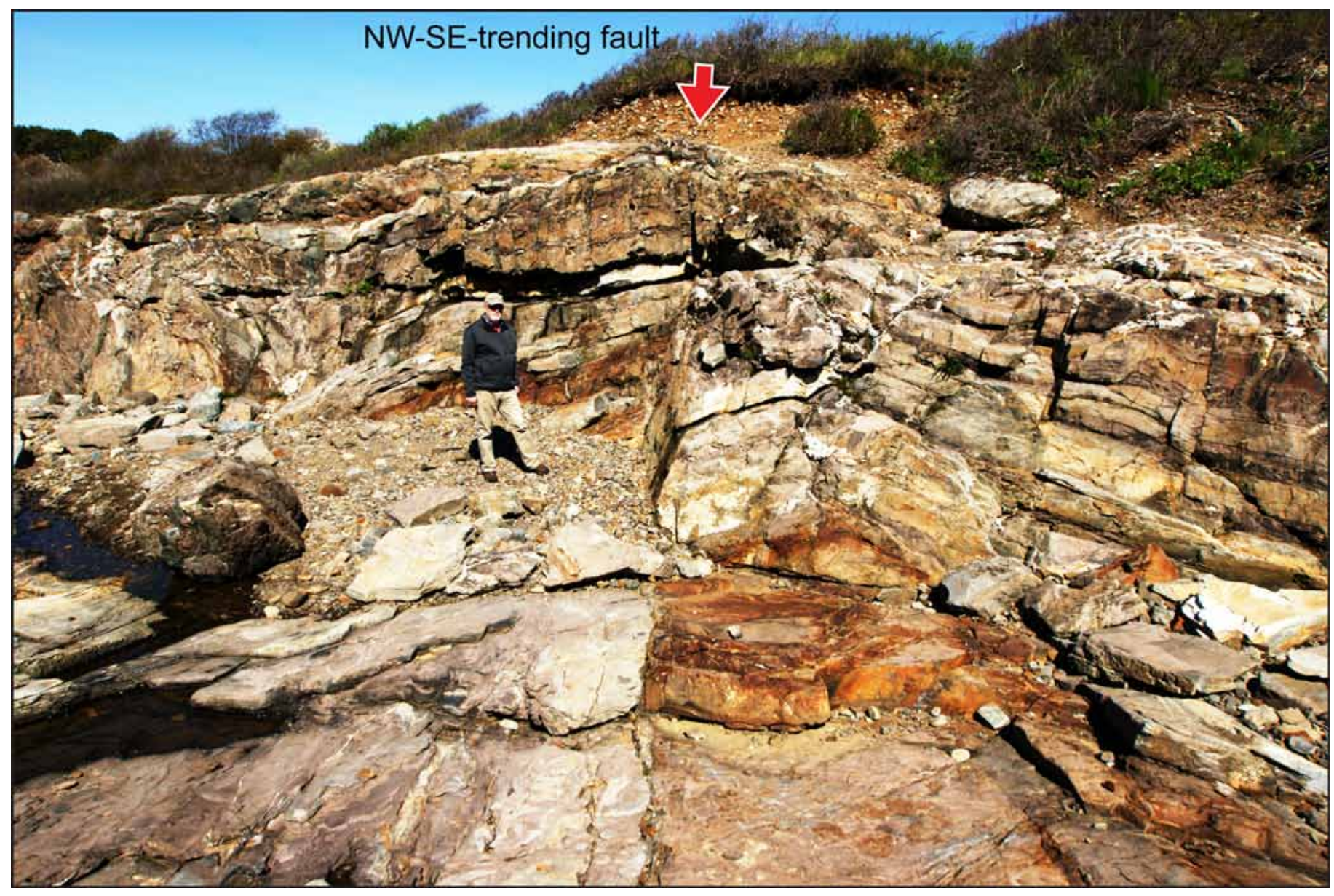

Figure 28. Photograph of NW-SE-trending fault in the Kittery Formation at Biddeford Pool, Maine (location shown in Figure 3b). Mark Swanson is standing on the hanging wall side of the fault.

Quaternary tectonism versus glacial unloading in southern Maine and New Hampshire

Various observations suggest that some of the proposed faults in the study area have undergone small vertical displacements during Pleistocene and possibly Holocene time. One such observation is the 3 - to 5 -m-high, east-facing Peverly Brook scarp (Fig. 7c) that is developed in Pleistocene sediments. As stated earlier, its oblique orientation relative to nearby recessional moraines (Marple et al. 2015) suggests that it could be a Pleistocene fault scarp.
The linear SE-facing scarps that cross Pleistocene drumlins east of Berwick, Maine (Fig. 9), may also be Pleistocene fault scarps with as much as $15 \mathrm{~m}$ of cumulative vertical displacement. These scarps are not landslides because head scarps of landslides are curved. Moreover, these scarps are formed mostly in till deposits that are not as susceptible to landsliding as the finer sediments of the Presumpscot Formation (Dickson and Johnston 2015). Furthermore, the base of these scarps coincide with much longer linear depressions that disrupt the otherwise smoothed linear 


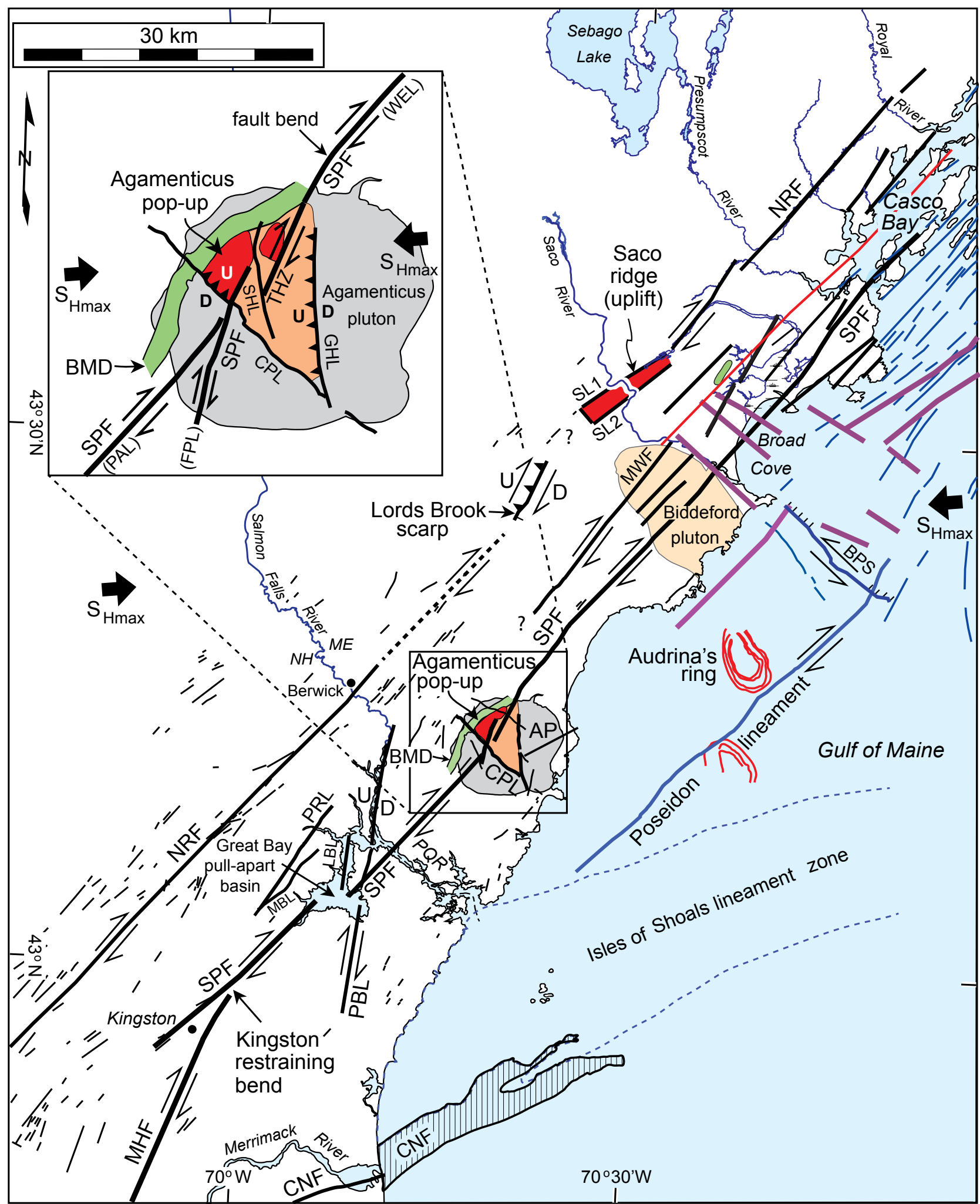

Figure 29. Tectonic model for the study area. The predicted fault motions are based on the orientations of faults relative to $\mathrm{S}_{\mathrm{Hmax}}$. AP is the Agamenticus pluton. The Agamenticus pop-up and Saco ridge are represented by red patterns. The inset in the upper left is an enlarged view of interpreted structures across the Agamenticus pluton. Abbreviations for faults and lineaments are listed in Tables A1 and A2 in the Appendix. PQR is the Piscataqua River. 

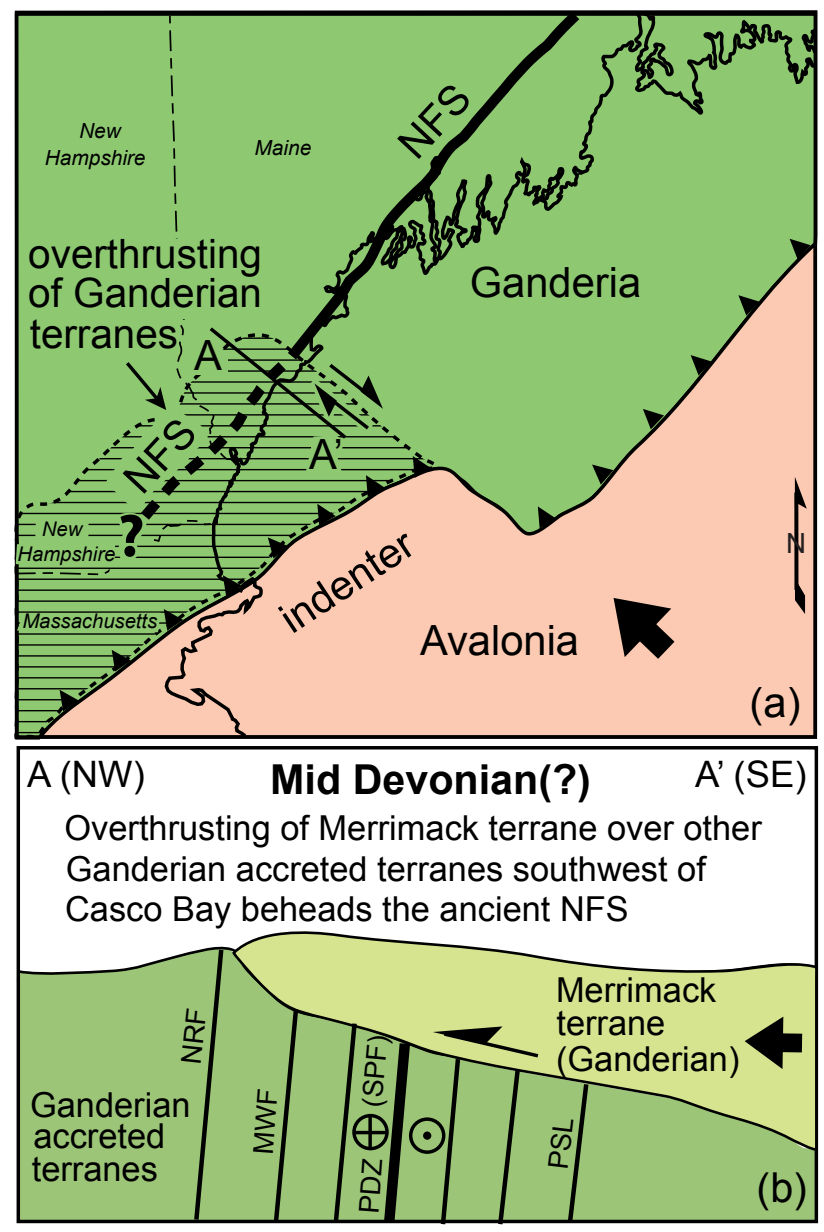

A (NW) Present erosion surface $A^{\prime}(\mathrm{SE})$

Reactivation of the NFS at depth fractures through the overlying Merrimack terrane

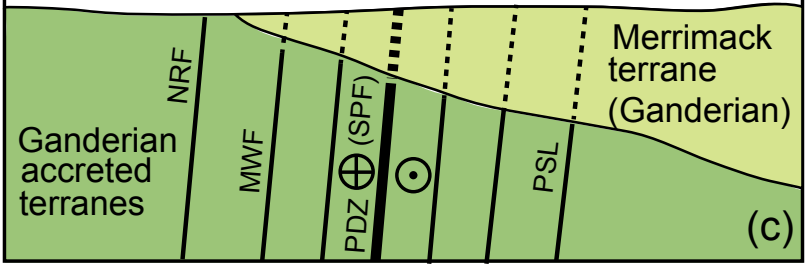

Figure 30. Conceptual diagram showing how the Norumbega fault system (NFS) southwest of Casco Bay was beheaded during overthrusting of the Merrimack terrane by a mid-Devonian indenter to the southeast. (a) Map showing conceptual model of northwest-directed indention southwest of Casco Bay, Maine. (b) Crosssection showing the beheading of the NFS southeast of the NRF in the upper crust by the Merrimack terrane during mid-Devonian(?). PDZ is the principal displacement zone (SPF?) of the NFS. (c) Later reactivation of the ductile roots of the NFS at depth fractured through the overlying Merrimack terrane and plutons (dashed lines) to produce the numerous NE-SW-trending LiDAR lineaments southwest of the Saco River. appearance of the drumlins (Fig. 9). Lastly, the low ridges along the crests of these scarps (Figs. 9a and 10) are best explained by compressional uplift along the interpreted faults responsible for the scarps.

The SE-facing scarp along the Old Mountain Road drumlin near the center of the Agamenticus pluton (Figs. 25 and 26) may also be a Pleistocene fault scarp. If true, then the fault along the Agamenticus Village lineament has undergone as much as $13 \mathrm{~m}$ of up-to-the-NW displacement during Pleistocene or early Holocene time.

Vertical displacements caused by rapid glacial unloading may have produced these scarps. The $150-\mathrm{km}$-long, 10-m-high Pärve fault scarp in Sweden, for example, is inferred to have ruptured during a single reverse event with a moment magnitude of $8.2 \pm 0.2$ (Arvidsson 1996) at 9.5 ka (Lagerbäck 1992). Alternatively, these scarps may have formed by multiple Pleistocene displacements.

Deformation associated with the changes in sinuosity and increased incision along the Kennebunk River where it crosses the interpreted SPF (Fig. 11b) is consistent with studies of river morphology (e.g., Schumm 1993), which indicate that these types of river anomalies are associated with gentle, late Pleistocene or Holocene uplift along faults. Conversely, these anomalies are not from changes in sediment type nor are they from a change in base level caused by a lowering of sea level because no still stand occurred near this area since the last ice age (Kelley et al. 1996). The rapids along the Saco River and Cascade Brook (Fig. 3b) are also possibly from up-to-the-west- displacements along faults associated with the West Brook and Blue Point lineaments, which are located just downstream from these rapids. The timing of this interpreted uplift is unknown.

\section{CONCLUSIONS}

In conclusion, we postulate that the numerous NE-SWtrending LiDAR lineaments southwest of the Saco River in southern Maine and southeastern New Hampshire are associated with post-Triassic low-displacement faults along the southwest continuation of the NFS. The small displacements of these faults and the presence of a major NW-SE-trending cross-structure near Biddeford, Maine, suggests that the Merrimack terrane southwest of Casco Bay may have been thrust over the ductile roots of the NFS during Devonian time by the interpreted Biddeford indenter. Reactivation of the Norumbega's ductile roots since then has fractured through the overlying Merrimack and other accreted terranes and plutons to form low displacement faults associated with the NE-SW-trending LiDAR and sonar lineaments southwest of Casco Bay, both onshore and offshore. Although the style and magnitude of displacements along the NFS southwest of Casco Bay are unknown, small (< $1 \mathrm{~km}$ ) dextral displacements along the NFS to the southwest 
are favored by its oblique orientation relative to the ENEWSW-oriented $S_{\mathrm{Hmax}}$ in the northeastern U.S. since at least early Tertiary time (Faure et al. 1996) and the low faultslip rates in the eastern U.S. since Early Cretaceous time (Prowell and Obermeier 1991). This conclusion is favored by the interpreted right-lateral displacements ranging from 30 to $500 \mathrm{~m}$ near the southwestern side of the Agamenticus pluton. We further conclude that the scarps crossing some of the Pleistocene drumlins to the southwest represent upto-the-west displacements along various faults of the NFS, either by rapid glacial unloading or multiple Pleistocene earthquakes. We further conclude that the sinuosity change and entrenchment along the Kennebunk River southwest of the Biddeford pluton is evidence for gentle Holocene deformation along the proposed SPF.

\section{ACKNOWLEDGEMENTS}

We thank reviewer Randy Cox, who originally reviewed this manuscript for Northeastern Geoscience, and an anonymous reviewer for their many constructive comments. We also thank James Ebert, Ed Stander, and Paul Washington, the editors of Northeastern Geoscience, for permission to publish instead in Atlantic Geology, and Atlantic Geology editors David West and Sandra Barr for their scientific feedback and help in reformatting the manuscript for that journal.

\section{REFERENCES}

Allmendinger, R. W., Cardozo, N. C., and Fisher, D. 2013. Structural Geology Algorithms: Vectors \& Tensors: Cambridge, England, Cambridge University Press, 289 p. https://doi.org/10.1017/cbo9780511920202.006

Arvidsson, R. 1996. Fennoscandian earthquakes: whole crustal rupturing related to post-glacial rebound. Science, 274, pp. 744-746. https://doi.org/10.1126/science.274. 5288.744

Berry, H.N., IV and Hussey, A.M., II. 1998. Bedrock geology of the Portland 1:100,000 quadrangle, Maine and New Hampshire. Maine Geological Survey, Open-File Map 98-1.

Bothner, W.A. and Hussey, A.M., II. 1999. Norumbega connections: Casco Bay, Maine, to Massachusetts? In Norumbega fault system of the northern Appalachians. Edited by A. Ludman and D.P. West, Jr. Geological Society of America, Special Paper, 331, pp. 59-72. https:// doi.org/10.1130/0-8137-2331-0.59

Cardozo, N. and Allmendinger, R.W. 2013. Spherical projections with OSXStereonet. Computers \& Geosciences, 51, pp. 193-205. https://doi.org/10.1016/j. cageo.2012.07.021
Daniels, D.L. and Snyder, S.L. 2004. New England states aeromagnetic and gravity maps and data - a web site for distribution of data. United States Geological Survey, Open-File Report 2004-1258. https://doi.org/10.3133/ ofr20041258

Dickson, S.M. and Johnston, R.A. 2015. Geomorphology of Presumpscot Formation landslides. Maine Geological Survey, Department of Agriculture, Conservation \& Forestry, Symposium on the Presumpscot Formation, 18 p. https://doi.org/10.1130/abs/2019ne-327955

Doll, W.E., Domoracki, W.J., Costain, J.K., Çoruh, C., Ludman, A., and Hopeck, J.T. 1996. Seismic reflection evidence for the evolution of a transcurrent fault system: the Norumbega fault zone, Maine. Geology, 24, pp. 251-254. https://doi.org/10.1130/0091-7613(1996)024<0251:srefte $>2.3 . \mathrm{co} ; 2$

Ebel, J.E. and Spotila, J.A. 1999. Modern earthquake activity and the Norumbega fault zone. In Norumbega fault system of the northern Appalachians. Edited by A. Ludman and D.P. West, Jr. Geological Society of America, Special Paper 331, pp. 195-202. https://doi.org/10.1130/0-81372331-0.195

Faure, S., Tremblay, A., and Angelier, J. 1996. State of intraplate stress and tectonism of northeastern America since Cretaceous time, with particular emphasis on the New England-Quebec igneous province. Tectonophysics, 255, pp. 111-134. https://doi.org/10.1016/0040-1951 (95)00113-1

Gaudette, H.E., Kovach, A., and Hussey, A.M., II. 1982. Ages of some intrusive rocks of southwestern Maine, USA. Canadian Journal of Earth Sciences, 19, pp. 1350-1357. https://doi.org/10.1139/e82-117

Gentry, E.N., Kuiper, Y.D., Holm-Denoma, C.S., and Hepburn, J.C. 2018. Characterizing the southwestern extent of the Norumbega fault system, a mid-Paleozoic crustal-scale strike-slip fault system in the New England Appalachians. Geological Society of America Northeastern Section, Abstracts with Programs, 50, https://doi.org/10.1130/abs/2018ne-311198

Goldstein, A. and Hepburn, J.C. 1999. Possible correlations of the Norumbega fault system with faults in southeastern New England. In Norumbega fault system of the northern Appalachians. Edited by A. Ludman and D.P. West, Jr. Geological Society of America, Special Paper 331, pp. 73-83. https://doi.org/10.1130/0-8137-2331-0.73

Guccione, M., Marple, R., and Autin, W. 2005. Evidence for Holocene displacements along the Bootheel fault (lineament) in Southeastern Missouri: seismotectonic implications for the New Madrid region. Geological Society of America Bulletin, 117, pp. 319-333. https://doi. org/10.1130/b25435.1

Hibbard, J.P., van Staal, C.R., Rankin, D., and Williams, H. 2006. Lithotectonic map of the Appalachian orogeny (North), Canada-United States of America. Geological 
Survey of Canada, Map 02041A, 1 sheet, scale 1:1 500000. https://doi.org/10.4095/221932

Hunter, L.E. 1999. Surficial geology of the Bar Mills 7.5-minute quadrangle, York County, Maine. Maine Geological Survey, Open-File Report 99-108, 9 p., 1 sheet, scale 1:24 000 .

Hussey, A.M., II. 2003a. Bedrock geology of the Old Orchard Beach quadrangle, Maine. Maine Geological Survey, Open-File Map 03-96, 7 p., 1 sheet, scale 1:24 000.

Hussey, A.M., II. 2003b. Bedrock geology of the Portland East quadrangle, Maine. Maine Geological Survey, OpenFile Map 03-90, 12 p., 1 sheet, scale 1:24 000.

Hussey, A.M., II. 2003c. Bedrock geology of the Portland West quadrangle, Maine. Maine Geological Survey, Open-File Map 03-93, 12 p., 1 sheet, scale 1:24 000.

Hussey, A.M., II. 2003d. Bedrock geology of the Prouts Neck quadrangle, Maine. Maine Geological Survey, Open-File Map 03-95, 8 p., 1 sheet, scale 1:24 000.

Hussey, A.M., II, Bothner, W.A., and Aleinikoff, J. 2010. The tectono-stratigraphic framework and evolution of southwestern Maine and southeastern New Hampshire. The Geological Society of America, Memoir 206, pp. 205230. https://doi.org/10.1130/2010.1206(10)

Hussey, A.M., II, Bothner, W.A., and Thompson, P.J. 2016. Bedrock geology of the Kittery 1:100,000 quadrangle, southwestern Maine and southeastern New Hampshire. Maine Geologic Survey, Bulletin 45, 99 p., 1 sheet.

Kelley, J.T., Dickson, S.M., and Belknap, D. 1996. Maine's history of sea-level changes. Maine Geological Survey, 16 p. URL <https://www.maine.gov/dacf/mgs/explore/ marine/facts/sealevel.pdf> 29 June 2019.

Kuiper, Y.D. and Wakabayashi, J. 2018. A comparison between mid-Paleozoic New England, USA, and the modern western USA: subduction of an oceanic ridgetransform fault system. Tectonophysics, 745, pp. 278-292. https://doi.org/10.1016/j.tecto.2018.08.020

Lagerbäck, R. 1992. Dating of late Quaternary faulting in northern Sweden. Journal of the Geological Society of London, 149, pp. 285-291. https://doi.org/10.1144/ gsjgs.149.2.0285

Ludman, A. and West, D.P., Jr. (Editors) 1999. The Norumbega fault system of the northern Appalachians. Geological Society of America, Special Paper 331, 199 p. https://doi.org/10.1130/0-8137-2331-0

Ludman, A., Lanzirotti, A., Lux, D., and Chunzeng, W. 1999. Constraints on timing and displacement of multistage shearing in the Norumbega fault system, eastern Maine. In Norumbega fault system of the northern Appalachians. Edited by A. Ludman and D.P. West, Jr. Geological Society of America, Special Paper 331, pp. 179-194. https://doi. org/10.1130/0-8137-2331-0.179

Lyons, J.B., Bothner, W.A., Moench, R.H., and Thompson, J.B. 1997. Bedrock geologic map of New Hampshire, New Hampshire Department of Environmental Services, 2 sheets, scale 1:125 000.

Marple, R.T. and Hurd, J.D., Jr. 2019. Sonar and LiDAR investigation of lineaments offshore between central New England and the New England seamounts, USA. Atlantic Geology, 56, pp. 57-91. https://doi.org/10.4138/ atlgeol.2019.002

Marple, R.T., Altamura, R. J., and Hurd, J.D., Jr. 2015. Peverly Brook scarp and lineament of southeastern New Hampshire, USA: a late Pleistocene or younger fault scarp? Seismological Research Letters, 86, pp. 616. https:// doi.org/10.1130/abs/2016am-287827

Marple, R.T., Hurd, J.D., Jr., and Altamura, R.J. 2018a. Ringshaped morphological features and interpreted small seamounts between southern Quebec (Canada) and the New England seamounts (USA) and their possible association with the New England hotspot track. Atlantic Geology, 53, pp. 223-265. https://doi.org/10.4138/atlgeol. 2018.008

Marple, R.T., Hurd, J.D., Jr., Liu, L., Travis, S., and Altamura, R.J. 2018b. Investigation of the 1727 Newbury, Massachusetts, USA, earthquake using LiDAR imagery and P-wave velocity tomography. Atlantic Geology, 53, pp. 267-283. https://doi.org/10.4138/atlgeol.2018.009

Marvinney, R.G. 1995. Bedrock geology of the Bar Mills quadrangle, Maine. Maine Geological Survey, Open-File Report 95-75, 7 p., 1 sheet, scale 1:24 000.

MEGIS. 2016. Maine Office of GIS, Maine Geolibrary, Office of Information Technology, Maine GIS Users Group, Lidar for the Northeast. URL <https://www1.maine.gov/ megis/projects/lidar.shtml> 1 November 2016.

Meglioli, A. 1999. Surficial geology of the Waterboro 7.5-minute quadrangle, York County, Maine. Maine Geological Survey, Open-File Report 99-134, 7 p. 1 sheet, scale 1:24000.

Mitra, S. and Paul, D. 2011. Structural geometry and evolution of releasing and restraining bends: insights from laser-scanned experimental models. American Association of Petroleum Geologists, 95, pp. 1147-1180. https://doi.org/10.1306/09271010060

Neil, C.D. 1999. Surficial geology of the Alfred quadrangle, Maine. Maine Geological Survey, Open-File Map 99-76, 1 sheet, scale 1:24 000 .

NH GRANIT. 2016. The New Hampshire Geographically Referenced Analysis and Information Transfer System, Earth Systems Research Center, Institute for the Study of Earth, Oceans, and Space, University of New Hampshire. URL <http://www.granit.edu/> 1 November 2016.

Osberg, P.H., Hussey, A.M., II, and Boone, G.M. 1985. Bedrock geologic map of Maine, Maine Geological Survey, 1 sheet, scale 1:500 000.

Prowell, D.C. and Obermeier, S.F. 1991. Evidence of Cenozoic tectonism. In The geology of the Carolinas. Edited by J.W. Horton, Jr. and V.A. Zullo. Carolina Geological Society Fiftieth Anniversary Volume. Knoxville, University of 
Tennessee Press, pp. 309-318.

Roden-Tice, M.K. and West, D.P. 2003. Late Cretaceous reactivation of the Norumbega fault zone, Main: evidence from apatite fission-track ages. Geology, 31, pp. 649-652. https://doi.org/10.1130/0091-7613(2003)031<0649:1crot $\mathrm{n}>2.0 . \mathrm{co} ; 2$

Schumm, S.A. 1993. River response to baselevel change: implications for sequence stratigraphy. The Journal of Geology, 101,pp.279-294.https://doi.org/10.1086/648221

Smith, G.W. 1998. Surficial materials map of the Wells Quadrangle, Maine. Maine Geological Survey, Open-File No. 98-164, 1 sheet, scale 1:24 000.

Smith, G.W. 1999a. Surficial geology of the Dover East 7.5-minute quadrangle, York County, Maine. Maine Geological Survey, Open-File Report 99-113, 10 p., 1 sheet, scale 1:24000.

Smith, G.W. 1999b. Surficial geology of the Kennebunk 7.5-minute quadrangle, York County, Maine. Maine Geological Survey, Open-File Report 99-117, 9 p., 1 sheet, scale 1:24 000 .

Smith, G.W. 1999c. Surficial geology of the North Berwick 7.5-minute quadrangle, York County, Maine. Maine Geological Survey, Open-File Report 99-92, 1 sheet, scale 1:24000.

Smith, G.W. 1999d. Surficial geology of the Somersworth 7.5-minute quadrangle, York County, Maine. Maine Geological Survey, Open-File Report 99-130, 7 p., 1 sheet, scale 1:24000.

Smith, G.W. 1999e. Surficial geology of the Wells 7.5-minute quadrangle, York County, Maine. Maine Geological Survey, Open-File Report 99-135, 8 p., 1 sheet, scale 1:24 000 .

Steltenpohl, M., Zietz, I., Horton, J.W., and Daniels, D.L. 2010. New York-Alabama lineament: a buried right-slip fault bordering the Appalachians and mid-continent North America. Geology, 38, pp. 571-574. https://doi. org/10.1130/g30978.1
Stevenson, D., Gangopadhyay, A., and Talwani, P. 2006. Booming plutons: source of microearthquakes in South Carolina. Geophysical Research Letters, 33, 4 p., L03316, https://doi.org/10.1029/2005gl024679

Swanson, M.T. 2019. NW-trending structures in southern coastal Maine: reoriented by steeply-plunging F3 folds related to regional Norumbega shear. Geological Society of America, Abstracts with Programs, 51, https://doi. org/10.1130/abs/2019ne-328298

Thompson, W.B. and Borns, H.W., Jr. 1985. Surficial geologic map of Maine. Maine Geological Survey, 1 sheet, scale 1:500 000 .

Wallace, R.E. (Editor) 1990. The San Andreas fault system. United States Geological Survey, Professional Paper 1515, $279 \mathrm{p}$.

Wang, C. and Ludman, A. 2003. Evidence for post-Acadian through Alleghanian deformation in eastern Maine: multiple brittle reactivation of the Norumbega fault system. Atlantic Geology, 38, pp. 37-52. https://doi. org/10.4138/1254

Wang, C. and Ludman, A. 2004. Deformation conditions, kinematics, and displacement history of shallow crustal ductile shearing in the Norumbega fault system in the Northern Appalachians, eastern Maine: Tectonophysics, 384, pp. 129-148. https://doi.org/10.1016/j.tecto.2004. 03.013

West, D.P. and Hubbard, M.S. 1997. Progressive localization of deformation during exhumation of a major strike-slip shear zone: Norumbega fault zone, south-central Maine, USA. Tectonophysics, 273, pp. 185-201. https://doi.org/ 10.1016/s0040-1951(96)00306-X

Zoback, M.L. and Zoback, M.D. 1991. Tectonic stress field of North America and relative plate motions. In Neotectonics of North America. Edited by D.B. Slemmons, E.R. Engdahl, M.D. Zoback, and D.D. Blackwell. Geological Society of America Decade Map, Boulder, Colorado, 1, pp. 339-366. https://doi.org/10.1130/dnag-csms-neo.339

Editorial responsibility: Sandra M. Barr 
Table A1. Fault name abbreviations.

BBF - Bloody Bluff fault

BCF - Broad Cove fault (NFS)

BTF - unnamed fault of Berry and Hussey (1998)

CEF - Cape Elizabeth fault (NFS)

CNF - Clinton-Newbury fault

DPF - Dover Point fault

FPF - Flying Point fault (NFS)

FRF - Fore River fault (NFS)

GBF - Great Bay fault

GCF - Great Commons fault

GSF - General Sullivan fault

HF1-HF2 - unnamed brittle faults of Hussey et al . (2016)

HHF - Honey Hill fault

HVSZ - Hope Valley shear zone
JPF - Johns Point fault (NFS)

LCF - Lake Char fault

MHF - Misery Hill fault

MWF - Mackworth fault (NFS)

$\mathrm{NBF}$ - Newburyport fault

NFS - Norumbega fault system

NIF - Nannie Island fault

NRF - Nonesuch River fault (NFS)

NRF-H - Nonesuch River fault of Hussey et al . (2016)

NRF-O - Nonesuch River fault of Osberg et al . (1985)

PF - Portsmouth fault

Scr - phyllonite at Church Road

SPF - South Portland fault (NFS)

Table A2. Abbreviations for names of lineaments, scarps, and topographic depressions and highs.

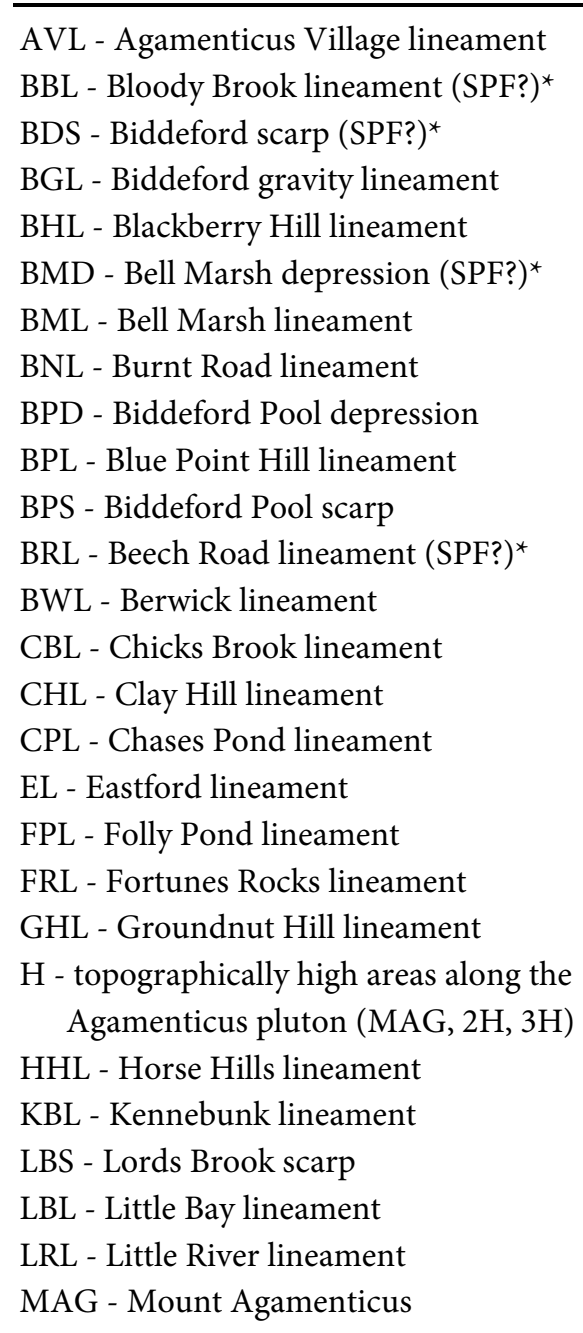

AVL - Agamenticus Village lineament

$\mathrm{BBL}-$ Bloody Brook lineament $(\mathrm{SPF} ?)^{\star}$

(SPF?)

BHL - Blackberry Hill lineament

BMD - Bell Marsh depression (SPF?)

BML - Bell Marsh lineament

BPD - Biddeford Pool depression

BPL - Blue Point Hill lineament

BPS - Biddeford Pool scarp

BRL - Beech Road lineament (SPF?)

BWL - Berwick lineament

CBL - Chicks Brook lineament

${ }^{\star}$ Lineaments that coincide with the interpreted southwest continuation of the SPF.

\author{
MBL - Moon Brook lineament \\ MGL - MacIntire Garrison lineament \\ MPL - Middle Pond lineament \\ MRL - Merriland River lineament \\ NRL - Neoutaquet River lineament \\ PBL - Peverly Brook lineament \\ PBS - Peverly Brook scarp \\ PAL - Payneton lineament (SPF?) ${ }^{\star}$ \\ PRL - Piscassic River lineament \\ PSL - Poseidon lineament \\ SBL - Saco Bay magnetic lineament \\ SHL - Second Hill lineament \\ SCL - Scotland lineament \\ SL1 - Saco lineament 1 \\ SL2 - Saco lineament 2 \\ STL - Stratham lineament \\ SWL - Stroudwater lineament \\ THZ - Third Hill zone of linear depressions \\ WBL - West Brook lineament \\ WCL - Wolf Creek lineament \\ WEL - Wells lineament (SPF?)* \\ WML - Wells magnetic lineament \\ WRL - Webhannet River lineament \\ YWL - York Woods lineament \\ ZLL - Zone of LiDAR lineaments \\ $2 \mathrm{H}$ - Second Hill \\ $3 \mathrm{H}$ - Third Hill
}

